Review

\title{
Recent Advances in Momordica charantia: Functional Components and Biological Activities
}

\author{
Shuo Jia, Mingyue Shen, Fan Zhang and Jianhua Xie * \\ State Key Laboratory of Food Science and Technology, Nanchang University, Nanchang 330047, China; \\ jiashuo@email.ncu.edu.cn (S.J.); shenmingyue1107@ncu.edu.cn (M.S.); zhangfan@email.ncu.edu.cn (F.Z.) \\ * Correspondence: jhxie@ncu.edu.cn; Tel.: +86-0791-88304347
}

Received: 20 October 2017; Accepted: 22 November 2017; Published: 28 November 2017

\begin{abstract}
Momordica charantia L. (M. charantia), a member of the Cucurbitaceae family, is widely distributed in tropical and subtropical regions of the world. It has been used in folk medicine for the treatment of diabetes mellitus, and its fruit has been used as a vegetable for thousands of years. Phytochemicals including proteins, polysaccharides, flavonoids, triterpenes, saponins, ascorbic acid and steroids have been found in this plant. Various biological activities of M. charantia have been reported, such as antihyperglycemic, antibacterial, antiviral, antitumor, immunomodulation, antioxidant, antidiabetic, anthelmintic, antimutagenic, antiulcer, antilipolytic, antifertility, hepatoprotective, anticancer and anti-inflammatory activities. However, both in vitro and in vivo studies have also demonstrated that $M$. charantia may also exert toxic or adverse effects under different conditions. This review addresses the chemical constituents of $M$. charantia and discusses their pharmacological activities as well as their adverse effects, aimed at providing a comprehensive overview of the phytochemistry and biological activities of $M$. charantia.
\end{abstract}

Keywords: chemical components; Momordica charantia; phytochemistry; biological activities

\section{Introduction}

Since ancient times, a variety of plants have been used as medicine and vegetable throughout the world. The combination of medicine and vegetable usage have made Momordica charantia (Momordica species) popular for thousands of years. Momordica charantia (M. charantia) (Figure 1), a valuable plant, belongs to the Cucurbitaceae family; it is commonly known as bitter gourd, balsam pear, bitter melon, kugua or karela [1]. The generic name "Momordica" comes from Latin, meaning "to bite", which refers to its leaf with serrated edges which looks as if it has been bitten [2]. The plant lives up to its common name "bitter melon" or "bitter gourd", as all parts of the plant including the fruit taste very bitter [2,3]. $M$. charantia is widely cultivated in the tropical and subtropical regions of the world, such as India, Malaya, China, Thailand, Japan, Singapore, Vietnam, Amazon, East Africa, Brazil, China, Colombia, Cuba, Ghana, Haiti, India, Mexico, Malaya, New Zealand, Nicaragua, Panama, Middle East, Central and South America [4-6]. The fruit of $M$. charantia is oblong or spindle with pimples on the surface and resembles a small cucumber; young fruit is emerald green that turns orange when ripe [6,7], while the flesh becomes scarlet from white during maturation. The fruit can be used as food material in every stage between maturing, and it is commonly used as a vegetable in different parts of the world. 


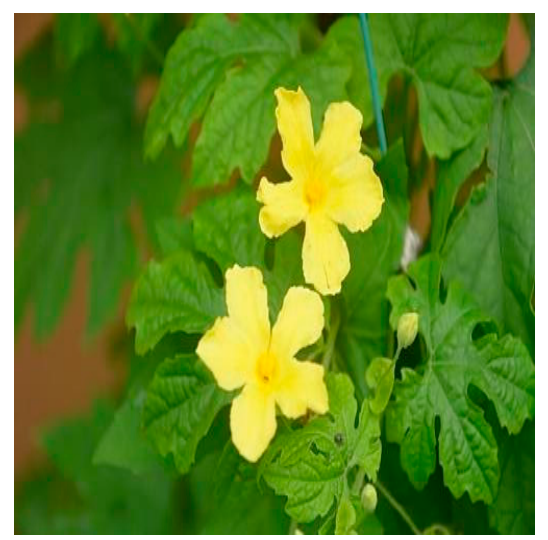

(a)

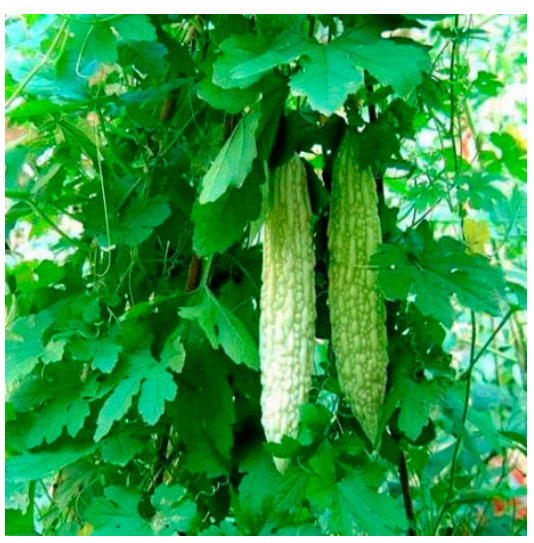

(b)

Figure 1. The above two pictures show the morphological characteristics of the M. charantia: (a) leaf and flowers (b) unripe fruits.

Although its fruit has a special bitter taste, $M$. charantia is popular among different people in the world. The phenomenon may be explained not only by its special taste but also the various bioactive effects which general vegetables do not provide. In many countries and regions, $M$. charantia also has been used as herbal medicine. The whole plant, especially the seeds and fruit, have significant pharmacological effects; for example, it has been used in the treatment of diabetes since ancient times, and still plays an important role in the prevention and remedy of diabetes in many developing countries [8,9]. Fractions of $M$. charantia, such as fruits, vines, leaves and even roots have been used as folk medicine for the remedy of diseases like toothache, diarrhea, furuncle and diabetes. Relevant products of $M$. charantia are quite popular now; for example the bitter gourd tea, which is known as gohyah or herbal tea made from dried slices, is applied mainly for medicinal purposes. The number of related articles published each year on the SCI website (Figure 2) demonstrate the steady and increasing trend in the number of research papers produced per year with $M$. charantia as a keyword. This plant is a traditional herbal medicine, possesses various pharmacological functions, namely antidiabetic, abortifacient, anthelmintic, contraceptive, antimalarial and laxative. It is used for the treatment of dysmenorrhea, eczema, gout, jaundice, leprosy, piles, pneumonia, psoriasis, rheumatism and scabies $[8,10,11]$.

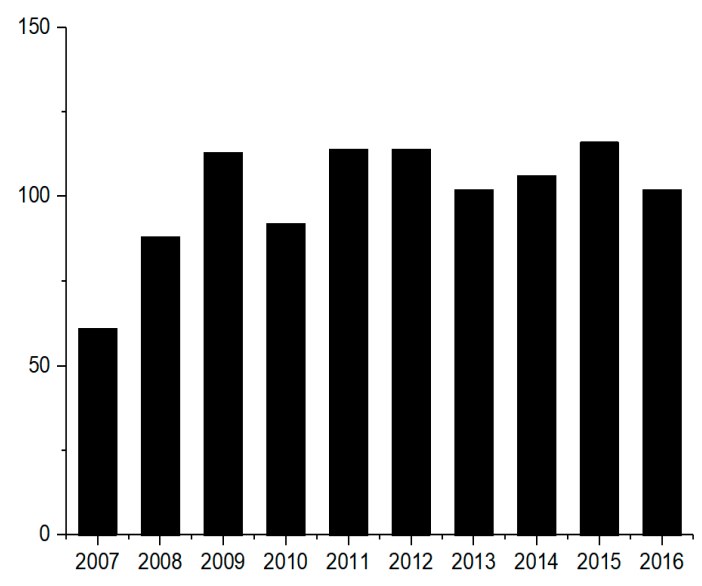

Figure 2. Articles published in Web of Science with M. charantia as a keyword in the last decade.

Several medicinal properties of $M$. charantia have been studied that include hypoglycemic, anti-bacterial, anti-viral, anti-tumor, immunomodulation, anti-oxidant, anti-diabetes, anthelmintic, antimutagenic, antilipolytic, antifertility, hepatoprotective and anti-inflammatory activities, as well 
as anti-ulcerogenic, anti-oxidative and immune-modulatory acivities. [12-14]. In vitro, studies have confirmed that $M$. charantia proteins ( $\alpha$-and $\beta$-momorcharin) have inhibitory effect against human immune deficiency virus (HIV). Its extract can also be used as a broad-spectrum antibacterial agent to fight off infections [15]. These beneficial effects are attributed to the various bioactive components of $M$. charantia, which are important sources of phytoconstituents used to treat various diseases since ancient times [16,17].

Though $M$. charantia possesses various pharmacological activities, there are also adverse effects that have been reported in the past years which limit its wider application. In addition to some toxic symptoms, previous studies have concluded that $M$. charantia may induce symptoms such as hypoglycemic coma in children, abortion or even death in laboratory animals [6].

This paper reviews various aspects of the results of investigations involving $M$. charantia in the recent years. It is aimed at providing a comprehensive overview of the phytochemistry and commercial application aspects of $M$. charantia to attract more attention to their biological activities, and to inform people for better utilization of $M$. charantia.

\section{Chemical Composition}

Several bioactive compounds of $M$. charantia fruit have been recorded in the literature; they are classified as carbohydrates, proteins, lipids and more [18-20]. M. charantia contains triterpenoids [21-24], saponins [25-27], polypeptides [28], flavonoids [29], alkaloids [30] and sterols [23]. Previous phytochemical studies have shown the bioactive components and their related functions (Table 1).

Table 1. Major bioactive components of M. charantia and their related functions.

\begin{tabular}{cccc}
\hline $\begin{array}{c}\text { Major Bioactive } \\
\text { Components }\end{array}$ & Functions & Distribution & Reference \\
\hline Polysaccharides & $\begin{array}{c}\text { Antioxidant, antidiabetic, immune } \\
\text { enhancement, neuroprotective, } \\
\text { antitumor }\end{array}$ & Various parts of plants & [31-36] \\
\hline Peptides and proteins & $\begin{array}{c}\text { RNA N-glycosidase, } \\
\text { polynucleotide adenosine } \\
\text { glycosidase (PAG), DNase-like, } \\
\text { phospholipase, superoxide } \\
\text { dismutase, anti-tumour, immune } \\
\text { suppression, antimicrobial }\end{array}$ & Seed & [37-43] \\
\hline Lipids & $\begin{array}{c}\text { Antitumor, antioxidant } \\
\text { Terpenoids }\end{array}$ & $\begin{array}{c}\text { Anticancer, antioxidant, } \\
\text { antidiabetic, hypoglycemic, cancer } \\
\text { chemoprevention }\end{array}$ & Stem, leave, fruit \\
\hline Saponins & $\begin{array}{c}\text { antihyperglycemic, hypolipidmic, } \\
\text { antiviral }\end{array}$ & Fruit, root, seed & {$[25,47-49]$} \\
\hline Phenolics & $\begin{array}{c}\text { Antioxidant, anti-inflammation, } \\
\text { immune enhancement }\end{array}$ & Fruit, pericarp, seed & {$[58-61]$} \\
\hline Sterols & Antimicrobial & Pericarp, fruit & {$[15,24,62]$} \\
\hline
\end{tabular}

\subsection{Polysaccharides}

Polysaccharides are among the important bioactive components of $M$. charantia. It has been shown that polysaccharides from $M$. charantia fruits possess various bioactivities, such as antioxidant, antidiabetic, immune enhancing, neuroprotective, antitumor and antimicrobial [31-36,63].

Extraction methods [64-66] such as traditional hot-water, acid and alkali extractions, as well as microwave-, ultrasonic- and enzymatic-assisted extractions, followed by ethanol precipitation have been applied for the separation of crude polysaccharides from M. charantia. Polysaccharides make up approximately $6 \%$ of bitter gourd powder, are classified as heteropolysaccharide, and are 
composed of galactose (Gal), glucose (Glu), arabinose (Ara), rhamnose (Rha) and mannose (Man) [66]. Deng et al. [67] showed that the contents of polysaccharides may be influenced by different conditions; the polysaccharide contents in 13 cultivated varieties range from $5.91 \%$ to $10.62 \%$ of dry powder. In addition, polysaccharides are classified in two main fractions; one of them has an average molecular weight $(M w)$ in the range of $1558.88-3048.56 \mathrm{kDa}$, and the other group is in the 33.1-58.74 kDa range. Tan and Gan [68] reported that an acidic and branched heteropolysaccharide (MCBP) isolated from M. charantia with a Mw of $92 \mathrm{kDa}$ was mainly composed of Man, galacturonic acid (GalA), Rha, Glu, Gal, xylose (Xyl) and Ara with molar ratios of 0.01:0.15:0.02:0.38:0.31:0.05:0.09, respectively. Furthermore, MCBP possessed antioxidant, $\alpha$-amylase inhibition and angiotensin-converting enzyme inhibition functions. A pectic polysaccharide (PS) was isolated and identified from M. charantia; its backbone is mainly composed of [4)- $\alpha$-D-GalpA6Me-(1 $\left.]_{3} \rightarrow 4\right)-\alpha$-D-GalpA6Me-(1 $\rightarrow$ [63]. It was composed of 1,4,5-tri-O-acetyl-2,3,6-tri-O-methyl-D-galactitol, 1,5-di-O-acetyl-2,3,4,6-tetra-O-methyl-D-galactitol, and 1,2,4,5-tetra-O-acetyl-3,6-di-O-methyl-D-galactitol, in the ratio of 3:1:1 and with $M w$ of $2 \times 10^{4} \mathrm{Da}$ [63]. Recently, a water-soluble polysaccharide (MBP) was isolated from M. charantia fruits, and mainly composed of Ara, Xyl, Gal and Rha in a molar ratio of 1.00:1.12:4.07:1.79, with Mw of $1.15 \times 10^{6} \mathrm{Da}$; it showed a significant hypoglycemic effect [31]. In particular, Raish [69] demonstrated that $M$. charantia polysaccharides ameliorate oxidative stress, hyperlipidemia, inflammation and apoptosis during myocardial infarction by inhibiting the NF-KB signaling pathway. M. charantia polysaccharides also had the ability to enhance total volatile fatty acids production, modulate the rumen fermentation pathway and influence the number of cellulolytic bacteria population [70].

\subsection{Proteins and Peptides}

Proteins and peptides are also the main functional components in the fruit and seeds of $M$. charantia. Many types of proteins and peptides have been isolated from different parts of $M$. charantia, such as ribosome inactivating proteins (RIPs), Momordica charantia lectin (MCL), Momordica anti-HIV protein of $30 \mathrm{kD}$ (MAP30), $\alpha$-momorcharin $(\alpha$-MMC), $\beta$-momorcharin ( $\beta$-MMC), $\gamma$-momorcharin, $\delta$-momorcharin and $\varepsilon$-momorcharin, which possess RNA $N$-glycosidase activity, PAG activity, DNase-like activity, phospholipase activity, superoxide dismutase activity, anti-tumour, anticancer, immunosuppressive and anti-microbial activity [37-43].

RIPs are a kind of RNA glycosylases that cleave an adenine-ribose glycosidic bond; it is a type of alkaline protein, which can inhibit the process of protein synthesis by inactivating ribosomes. They can be further divided into three classes; RIPs with only a RIP chain are classified as type I, and the structure of type II RIPs generally has two chains, A and B, which are interconnected by disulfide bonds [71]. And the structure of $B$ chain allow them binding with galactose residues on the oligosaccharide chain. There are also atypical type I RIPs (on the basis of their structure) which are classified as type III RIP [72].

M. charantia lectin (Type II RIP) and $\alpha$-MMC have been isolated from $M$. charantia seeds; it can significantly inhibit human nasopharyngeal cancer cells and xenograft tumors in vitro [43]. MCL is a type II RIP, known to be particularly toxic, and has been used as an anti-tumor agent [73]. Momordicin is also a type II (single-stranded) RIP that has been successfully isolated from M. charantia together with other factors.

MAP30 is a single chain RIP, named for its molecular mass of $30 \mathrm{kD}$; it has been found to have strong anti-tumor potential similar to MCL [38,71]. The protein also significantly inhibits proliferation and causes apoptosis in a panel of cancer cells from prostate, breast, lung, hepatocellular and brain glioblastoma [38]. The MAP30 protein consists of 286 amino acids and the mature protein contains one $\mathrm{N}$-glycosylation site and a glycosylase that aids in the binding of elongation factors [38].

Like MAP30, both $\alpha$-MMC and $\beta$-MMC are type I RIPs, containing only one enzymatic chain [72]. $\alpha$-MMC is also a $30-\mathrm{kDa}$ glycoprotein, while $\beta$-MMC is slightly smaller $(29-\mathrm{kD})$ glycoprotein. Both have anti-tumor activity individually. 
Polypeptide-P, a hypoglycemic peptide, is a kind of carbohydrate binding protein secreted by plant cells; it plays an important role in cell recognition and adhesion reactions. It is isolated from the fruit, seeds and tissues of $M$. charantia with a $M w$ of approximately $11 \mathrm{kD}$; it contains 166 amino acid residues and another polypeptide with a $M w$ of $3.4 \mathrm{kD}$ has also been isolated from bitter melon [74]. Other proteins and peptides, such as peroxidase (43 kDa), Momordica cyclic peptides [75], trypsin inhibitors (McTI-I, -II and -III), cystine knot peptides, RNase MC2 (14 kDa), antifungal protein and MCha-Pr have also been isolated from M. charantia [76].

\subsection{Saponins and Terpenoids}

Saponins are a class of glycosides in which the aglycone is a triterpenoid or a spiro-steroid compound. All of the compositions are of sugar and aglycone, and the difference between them lies in the structure of aglycones. Saponins are found in the roots, stems, leaves and fruit of the $M$. charantia. Research has shown that the major chemical constituents are tetracyclic triterpenoids and their glycosides, most of which are referred to as cucurbitanes, and are well-known for their bitterness and toxicity. The content of total saponins in M. charantia powder is about $0.0432 \%$ [77].

The saponins substances are the active ingredients of multiple drugs, widely distributed in a variety of plants [78], which contain triterpenoidal saponins (e.g., cucurbitacin alkyl type, oleanane type, ursane type) and steroidal saponins. The cucurbitacins are a group of bitter-tasting, highly-oxygenated, mainly tetracyclic, triterpenic plant substances derived from the cucurbitane skeleton. Many pharmacological studies further indicated that cucurbitanes from $M$. charantia are responsible for their anti-diabetic and hypoglycaemia activities [79]. Cucurbitane-type compounds, such as goyaglycosides a, b, c, d, e, f, g and h; goyasaponins I, II, and III; and momordicosides A, C, F , $\mathrm{I}$ and $\mathrm{K}$ have been isolated from the methanolic extract of $M$. charantia fruits [27]. Cucurbitane-type triterpenoids: $\beta, 19$-epoxy-3 $\beta, 25$-dihydroxycucurbita-6,23(E)-diene, and $3 \beta, 7 \beta, 25$-trihydroxycucurbita5,23(E)-dien-19-al were isolated from the methanol extract of $M$. charantia dried gourds, which could lower blood sugar in diabetic mice. Moreover, Harinantenaina et al. [80] also demonstrated that compounds of $M$. charantia have hypoglycaemic effects in vivo. Chang et al. [55] isolated four new cucurbitane-type triterpenes, cucurbita-5,23(E)-diene-3 $\beta, 7 \beta, 25$-triol, $3 \beta$-acetoxy-7 $\beta$-methoxycucurbita5,23(E)-dien-25-ol, cucurbita-5(10),6,23(E)-triene-3 $\beta, 25$-diol and cucurbita-5,24-diene-3,7,23-trione, from the methyl alcohol extract of $M$. charantia stems. In 2011, five kinds of saponins and cucurbitane triterpenoids, including $3 \beta, 7 \beta, 25$-trihydroxycucurbita-5,23(E)-dien-19-al, momordicine I, momordicine II, 3-hydroxycucurbita-5,24-dien-19-al-7,23-di-O- $\beta$-glucopyranoside and kuguaglycoside G were isolated from $M$. charantia. In another study, eight new cucurbitane-type glycosides, kugua saponins A-H and six known compounds, were isolated by the directed fractionation of $M$. charantia fruits [81]. Zhang et al. [82] also reported that four new cucurbitane-type triterpenes, (23R)-7 $\beta$-hydroxy-3 $\beta-O-$ malonyl-23-methoxycucurbita-5,24-diene-19-al, (23E)-7 $\beta, 25$-dihydroxy-3 $\beta$-O-methylmalonylcucurbita-5,23-

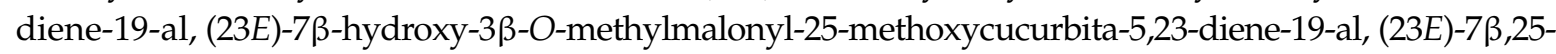
dihydroxy-3 $\beta$-O-crotonylcucurbita-5,23-diene-19-al, and one new glycoside $7 \beta$-hydroxy-3 $\beta$-O-malonylcucurbita-5,24-diene-19-a-23-O- $\beta$-D-glucopyranoside, were isolated from the rattans of wild $M$. charantia.

\subsection{Flavonoids and Phenolic Compounds}

Flavonoids and phenolic compounds are important components of $M$. charantia $[5,83]$. They include gallic acid, protocatechuic acid, gentistic acid, (+)-catechin, vanillic acid, syringic acid, (-)-epicatchin, p-coumaric acid, benzoic acid, sinapinic acid, o-coumaric acid, chlorogenic acid, $\mathrm{t}$-cinnamic acid and $\mathrm{t}$-ferulic acid. The most abundant flavonoids, quinic acid (145.279 ng/mg) and catechin $(57.24 \mathrm{ng} / \mathrm{mg}$ ), were determined in the BME4 $<3.5 \mathrm{kDa}$ (methanol hydrophilic extraction of M. charantia dialysis tubing with $3.5 \mathrm{kDa}$ ) by UPLC-MS [84]. Phenolic acid constituents were distributed in various amounts for each phenolic acid among a variety or parts of tissues [85]. In $M$. charantia flesh, the main phenolic acids were gallic acid, gentisic acid, catechin, chlorogenic acid and epicatechin, and ranged from 8.04 to $39.76,16.99$ to $32.39,23.06$ to $82.45,4.55$ to 15.83 , and 
16.14 to $44.28 \mathrm{mg} / 100 \mathrm{~g}$ dry material [85]. Ethyl acetate crude extract of $M$. charantia contained ascorbic acid (576.5 ng/mg), 3-coumaric acid ( $528.55 \mathrm{ng} / \mathrm{mg})$, luteolin-7-O-glycoside $(725.50 \mathrm{ng} / \mathrm{mg})$, apigenin-7-O-glycoside (1955.55 ng/mg), caffeic acid $(215.6 \mathrm{ng} / \mathrm{mg}$ ) and naringenin-7-O-glycoside $(181.30 \mathrm{ng} / \mathrm{mg}$ ) [84]. The amounts of protocatechuic acid, p-coumaric acid, syringic acid, vanillic acid and benzoic acid ranged from 2.07 to $8.78,1.83$ to $8.23,1.77$ to 3.67 and trace to $2.42 \mathrm{mg} / 100 \mathrm{~g}$ dry material in the flesh of all varieties of the bitter melons, respectively [85].

Catechin and epicatechin are the two most common flavonoids in plants. Budrat and Shotipruk [86] revealed that catechin is the highest phenolic acid contained in bitter melon ( $46.16 \mathrm{mg} / \mathrm{g}$ dry weight, $72-86 \%$ of the total phenolic contents) from the extracts obtained by subcritical water extraction, followed by gentisic acid (4-12\%), gallic acid $(0.25-0.87 \%)$ and chlorogenic acid $(0-0.26 \%)$, respectively. Main phenolic constituents in the extracts were catechin, gallic acid, gentisic acid, chlorogenic acid and epicatechin [87]. Caffeic acid is classified as a phenylpropanoid; the concentration of caffeic acid in bitter melon was found to be $3.55 \mathrm{mg} / \mathrm{L}$ in the methanolic fraction [88]. p-coumaric acid, tannic acid, benzoic acid, ferulic acid, gallic acid, caffeic acid, and (+)-catechin have also been found in aqueous extract fractions of $M$. charantia.

\subsection{Other Components}

Besides bioactive ingredients, unsaturated fatty acids, alkaloids, amino acids and minerals, vitamins are also contained in M. charantia [8,89-92]. The proportion of unsaturated fatty acid component in bitter melon is relatively high; monounsaturated fatty acids in the ratio of total fatty acid content are about $20.1 \%$, while polyunsaturated fatty acid content is about $64.3 \%$. Nine kinds of unsaturated fatty acids have been found in bitter melon extracts [84]. It has also been demonstrated that 12,13 and 12 fatty acids are found in young, mature, and senescent leaves of M. charantia L., representing $87.3 \%, 95.25 \%$, and $83.11 \%$ of the total fatty acids [93]. The contents of total amino acids and the free amino acids of $M$. charantia were $11.99 \%$ and $2.36 \%$ as determined by acid hydrolysis and amino acid analysis [94]. In addition, bitter melon is a natural source of vitamins; ascorbic acid was detected in the range of 440-780 $\mathrm{mg}$ in the fruit fraction [95].

\section{Biological Activities}

As M. charantia has been used for the treatment of various kinds of diseases since ancient times, it is still widely applied for therapy in Latin America and Asian countries as mentioned above. The following is an overview of its common pharmacological activities.

\subsection{Antidiabetic Activity}

Diabetes mellitus, one of the fastest growing diseases in the world, is a group of metabolic diseases characterized by hyperglycemia resulting from defects in insulin secretion, insulin action, or both [96]. Many studies suggest that a variety of $M$. charantia extract can be used as a remedy for the treatment of diabetes [8,31,97-101]. It has also been widely used as an antidiabetic drug in different countries for thousands of years $[8,10,102]$.

Many studies have demonstrated that $M$. charantia has potent antidiabetic activities through cell-based assays, animal models and human clinical trials [6,103-106]. Oral administration of the aqueous extract $M$. charantia fruits could significantly lower blood glucose level in streptozotocin- (STZ-) induced diabetic rats at a dose of $250 \mathrm{mg} / \mathrm{kg}$ [107]. The aqueous extract of $M$. charantia fruits can stimulate insulin secretion of $\beta$ cells in pancreatic islets isolated from obese-hyperglycemic mice [102]. Another study showed that M. charantia fruit aqueous extract also has hypoglycaemic activity in cyproheptadine-induced diabetic mice [108]. Orally administered $M$. charantia aqueous extracts lowered glucose concentrations independently of intestinal glucose absorption and involved extrapancreatic effects [103]. It also plays a role in the renewal of $\beta$ cells in STZ-diabetic rats or recovery of destroyed $\beta$ cells [12]. A boiling water extract from M. charantia has significant repairing effects on HIT-T15 cells against superoxide anion radicals, 
which showed potential cell repairing activity on alloxan-damaged HIT-T15 pancreatic $\beta$ cells; its fraction with a $M w$ below $3 \mathrm{kDa}(2 \%)$ performed better in stimulating insulin secretion [109]. It has also been reported that in clinical trials, polypeptide-P isolated from the bitter gourd was found to have hypoglycemic activity [110]. With the chronic administration of the M. charantia fruit juice at $20 \mathrm{mg} / \mathrm{kg}$ orally, blood glucose tolerance of alloxan-induced rats was ameliorated significantly from day 7 to day 22, and was reduced to normal levels [111]. The major pure cucurbutanoid compounds of $M$. charantia, $5 \beta, 19$-epoxy- $3 \beta, 25$-dihydroxycucurbita-6,23(E)-diene, and $3 \beta, 7 \beta, 25$-trihydroxycucurbita-5,23(E)-dien-19-al have been demonstrated to have hypoglycaemic effects in the diabetes-induced male ddY mice. Although the glucose lowering effects are lower than glibenclamide at the same concentration $(400 \mathrm{mg} / \mathrm{kg})$, they are still significant [80]. M. charantia fruit juice could significantly reduce blood glucose levels in alloxan-induced diabetic rats, and could restore the impaired estrous cycle in diabetic rats. The mechanisms by which $M$. charantia extracts act on diabetes are via both intra- and extra-pancreatic mechanisms [112]. Fernandes et al. [113] suggested that the antidiabetic mechanism of $M$. charantia extracts may be due to enhancing insulin secretion by the islets of Langerhans, reducing glycogenesis in liver tissue, enhancing peripheral glucose utilization and increasing serum protein levels.

\subsection{Anti-Oxidant Activity}

Many studies have demonstrated that $M$. charantia is a good natural source of antioxidants under experimental conditions; it possess an activity against oxidant damage in vitro and in vivo [48,60,114]; the bioactive phytochemicals mainly include polysaccharides, saponins and phenolics [9,91]. Bitter gourd pulp and its extracts, followed by seed powder and its ethanol/water extracts exhibited stronger anti-oxygenic activity than other solvent extracts, which were determined via several in vitro models [115]. ABTS radical cation-scavenging assays demonstrated that three new triterpenoids compounds isolated from $M$. charantia stems had a weaker effect compared to the control group, $\mathrm{IC}_{50}$ values were $268.5 \pm 7.9,352.1 \pm 11.5$ and $458.9 \pm 13.0 \mu \mathrm{M}$, respectively. But cucurbita-1(10),5,22, 24-tetraen-3a-ol showed a significant inhibition on XO at $100 \mu \mathrm{M}$ [48]. Supplementation of M. charantia $(13.33 \mathrm{~g} / \mathrm{kg})$ in diabetic rats significantly decreases $(p<0.001)$ TBARS levels and significantly increases antioxidants (SOD, CAT and GST) activities [116]. Oral administration of $M$. charantia lyophilized powder plays an important role in decreasing serum TBARS and maintaining the GSH content in alloxan-induced diabetes rats [104]. It has been reported that a wild variety of bitter gourd alcohol extract and aqueous extract have an effect in eliminating 1,1-diphenyl-2-trinitrobenzene hydrazine (DPPH) radical at $300 \mu \mathrm{g} / \mathrm{mL}$, as well as metal chelating activity at 100, 250,500 $\mu \mathrm{g} / \mathrm{mL}$ when compared with VE, but less capacity on inhibiting peroxidase and lipid peroxidation at all concentrations in different tissues [117]. The aqueous extract reduced the serum AST, ALT and NO content and the expression of hepatic iNOS; it protected liver from the damage-induced by mitochondrial ROS at each dose $(250,500$ and $750 \mathrm{mg} / \mathrm{kg})$ in the experiment [118]. After continuous administration for eight weeks (thrice a week, $300 \mathrm{mg} / \mathrm{kg}$ ), M. charantia alcoholic extract exerted antioxidant potentials by reversing the oxidant/antioxidant imbalance; changes in liver markers also suggest the extract maintained cellular integrity of the liver tissue in ammonium chloride-(AC-) induced hyperammonemia rats [114].

The antioxidant activities of the aqueous extracts of $M$. charantia pulp were evaluated using assays to assess DPPH and hydroxyl radical scavenging activities, metal-chelating activity and reducing power of the extracts [119]. The activity of a water-soluble pectic polysaccharide isolated from the hot water extract of the unripe $M$. charantia fruits on free radicals scavenging ability was assessed to be $\mathrm{EC}_{50}=2.22 \mathrm{mg} / \mathrm{mL}[64]$.

Flavonoids are known to be one of the most effective free radical scavengers and antioxidants from $M$. charantia. The antioxidant capacity enhanced gradually with the increase of flavonoid concentration, and the scavenging efficiency even reached $96.14 \pm 1.02 \%$ at the concentration of $1.2 \mathrm{mg} / \mathrm{mL}$ [5]. While there was also a big difference on antioxidant capacity between them, among the 13 substances identified as cucurbitane-type triterpene glycosides, compound $\mathbf{1}$ showed weak DPPH-scavenging 
activity but strong inhibitory effect on $\mathrm{XO}$ and ABTS radical. Antioxidant capacity was expressed as $\mathrm{O}_{2}$ scavenging activity for other compounds such as compound $\mathbf{2 - 4}$. Oxygen radical absorbance capacity (ORAC)-pyrogallol red (PGR) values were also differed between compounds $\mathbf{2}$ and $\mathbf{3}$ ( $0.88 \pm 0.02$ and $0.55 \pm 0.09$, respectively) [120]. 9c, 11t, 13t-conjugated linolic acid (CLN), mainly distributed in the bitter gourd seed, could significantly increase acyl CoA oxidase activity in a peroxisome proliferator responsive murine hepatoma cell line, H4IIEC3, and was identified as a PPAR $\alpha$ activator in wild bitter gourd, which could act on PPAR $\alpha$ signaling pathways [92]. For $\mathrm{H}_{2} \mathrm{O}_{2}$ and $\mathrm{HX}$-XO-induced oxidative damage models, total phenolic extracts from $M$. charantia showed a dose-dependent antioxidant effect on NIH 3T3 cardiac fibroblasts and A431 keratinocytes at the range of 50-300 $\mu \mathrm{g} / \mathrm{mL}$; the extract protected both cell lines from the damage of $\mathrm{H}_{2} \mathrm{O}_{2}$ at a concentration of $1 \times 10^{-4} \mathrm{~mol} / \mathrm{L}$ [121].

\subsection{Antiviral Activity}

Ethanolic extracts from leaves and stems of $M$. charantia highly inhibit HSV-1 and SINV viruses, and research also suggests that the antiviral activity reflects a close dependence on photosensitizer(s) rather than momordicin I or II [122]. A variety of compounds isolated from M. charantia have antiviral activity; many of them are proteins and steroids [123,124]. Kuguacin $C$ and Kuguacin E isolated from the root of $M$. charantia showed moderate anti-HIV-1 activity with $\mathrm{EC}_{50}$ values of 8.45 and $25.62 \mu \mathrm{g} / \mathrm{mL}$, while exerting minimal cytotoxicity on uninfected C8166 cells ( $\mathrm{IC}_{50}>200 \mu \mathrm{g} / \mathrm{mL}$ ) [21]. MAP30 is the main component of antiviral activity in vitro; it selectively kills lymphocytes and macrophage infected by HIV, inhibits HIV-I virus DNA replication in monocytes, while exerting minimal cytotoxicity on uninfected cells [125]. Similarly, research also found that MAP30 of bitter gourd proteins can inhibit HIV activity, depress the expression of the virus core protein p24 and viral-associated reverse transcriptase (HIV-RT), while having less effect on cellular DNA or protein synthesis in H9 cells [126]. MRK29, as a lectin isolated from $M$. charantia, was found to act through inhibition of viral reverse transcriptase [127]. Momordicin had direct protective effect on Coxsackie virus (CVB3)-infected myocardiocyte, and depressed RNA transcription and translation of CVB3 in myocardial cells [128].

\subsection{Antimicrobial Activity}

Essential oils of $M$. charantia seeds have significant inhibitory effect on S. aureus, while having less impact on E. coli and C. albicans [129]. The aqueous extract from M. charantia seed exhibited significant antimicrobial activity against several bacteria in the following ascending order: P. multocida, S. typhi, S. epidermidis and L. bulgaricus. As for the ethanolic extract, the sequence was S. aureus, M. luteus, E. coli, S. epidermidis and L. bulgaricus, while n-hexane and petroleum ether extracts were effective against S. aureus [130].

M. charantia pulp extract has been proven to have broad-spectrum antimicrobial activity [131], the same as the hydrophilic leaf extracts, which exhibited antibacterial activities against E. coli, Staphylococcus, Pseudomonas, Salmonella and Streptobacillus. This may be attributed to 5-a-stigmasta-7, 25-dien-3-b-ol, elasterol and lanosterol [15]. Ethanol extracts of $M$. charantia leaves exhibit inhibition on B. cereus and S. aureus. The ethanol fraction has no apparent effect on E. coli, which is in contrast with the treatment of the ethyl acetate extracts [132]. Methanolic extract from $M$. charantia leaves showed the strongest antibacterial activity amongst several organic solvent extracts, with a significant inhibitory effect on E. coli and S. aureus [133].

No inhibitory activity was observed against methicillin-resistant S. aureus or P. aeruginosa in either the hydrophilic or methanolic extracts of several wild M. charantia L. var. abbreviata Seringe cultivals, but some of them showed strong inhibitory effects on the growth of E. coli and S. enterica [134]. A low molecular mass peptide (approximately $10 \mathrm{kDa}$ ) purified from $M$. charantia is more effective against $S$. aureus and E. coli as compared to $S$. typhi and P. aeruginosa. As the concentration increased to $200 \mu \mathrm{g} / \mathrm{mL}$, apparent proliferation ratios of S. aureus, E. coli, S. typhi and P. aeruginosa were decreased by $57 \%, 49 \%, 29 \%$ and $18 \%$, respectively [42]. $\alpha$-MMC isolated from $M$. charantia strongly inhibited P. aeruginosa and the mycelial growth of F. solani and F. oxysporum [135]. The seed extracts also 
significantly inhibited the growth of $F$. solani in a dose-dependent manner, the probable explanation is that it undermined the integrity of the cell nucleus and DNA [136].

\subsection{Anti-Inflammatory Activity}

Oral administration of $2 \%$ and $5 \%$ M. charantia dry powder significantly depressed macrophage infiltration in epididymal adipose tissues (EAT) and brown adipose tissues (BAT) of rats fed with high-fat diet (HFD), and downregulated the expression of pro-inflammatory cytokine monocyte chemotactic protein-1, TNF- $\alpha$ and IL-6 in EAT [137]. However, an opposite result was observed which is that bitter melon powder could significantly improve the pro-inflammatory cytokines (TNF- $\alpha$, IL-6) and anti-inflammatory cytokine (IL-10) via suppressing the activation of NF- $\mathrm{kB}$ signaling pathways [138]. M. charantia normalized the content of neuroinflammatory markers (e.g., NF-B1, TNF- $\alpha$, IL-16, IL-22, IL-17R), significantly reduced brain oxidative stress induced by high fat diet administration and effectively prevented neuroinflammation [139]. Studies also found M. charantia suppressed the secretion of IL-7 and promoted the secretions of TGF- $\beta$ and IL-10, thereby leading to the decrease of lymphocytes and elevation in Th cells and natural killer (NK) cells in vivo [140].

Research on a cerebral ischemia-reperfusion injury model in male Sprague Dawley rats shows that $M$. charantia polysaccharides have neuroprotective effects against global cerebral ischemia/reperfusion injury by scavenging radicals $\left(\mathrm{O}_{2^{-}}, \mathrm{NO}\right.$ and $\left.\mathrm{ONOO}-\right)$ and reduces neural cell death in vitro; it also inhibits the release of cytochrome $\mathrm{C}$, phosphorylation of JNK3 and expression of Fas-L in both pre-ischemia and post-ischemia treatment [141]. Wild $M$. charantia in diets attenuated inflammatory stress in mice with sepsis through reduced secretions of pro-inflammatory cytokines and the expression of proteins (COX-2, iNOS and NF- $\mathrm{kB}$ ) associated with inflammation [142]. M. charantia polysaccharides enhanced the activity and production of superoxide dismutase, catalase, non-protein sulfhydryls and Bcl-2 in pretreated rats prior to isoproterenol-induced myocardial infarction, along with the expression of proinflammatory cytokines (IL-6 and IL-10), while inflammatory markers (nitric oxide, myeloperoxidase, and inducible NO synthase) and apoptotic markers (caspase-3 and BAX) were down-regulated [71]. For cyclophosphamide-treated mice, $M$. charantia polysaccharides normalized immunological parameters and there was no significant difference between the high-dose group (300 mg/kg/day) and normal control at day 30. The immunomodulatory activity mainly showed improved phagocytosis and NK cell vitality in comparison with the model control [33].

Total phenolic extracts of $M$. charantia significantly attenuated P. acnes-induced inflammatory responses, inhibited infiltrations of neutrophils and IL- $1 \beta$ leukocytes and NF- $\mathrm{kB}$ activation, depressed MMP-9 levels and the production of IL-8, IL-1 $\beta$, TNF- $\alpha$ in vitro, and inactivated mitogen-activated protein kinase (MAPK) [143].

\subsection{Anti-Tumor Activity}

M. charantia extracts and its monomer components have shown strong anticancer activity against various tumors such as lymphoid leukemia, lymphoma, choriocarcinoma, melanoma, breast cancer, skin cancer and prostate cancer [6]. Anti-CD5 monoclonal antibodies linked to momordin (a ribosome-inactivating protein purified from $M$. charantia) performed better than other anti-CD5-based immunoconjugates containing ricin A chain on human $\mathrm{T}$ cell leukemia Jurkat. In the model of nu/nu mice bearing Jurkat leukemia, animals treated with the immunotoxin suffered smaller tumor size and significant inhibition $(p<0.01)$ of the tumor development was observed at day 120 [144].

Whole fruit extracts of $M$. charantia elevated hepatic GST and -SH levels, significantly reduced the tumor burden in DMBA-induced papillomagenesis, and in the groups, no skin papillomas were observed during the entire experimental period [145]. As for PN-induced and TPA-promoted papillomagenesis in mice, the formation of papillomas was delayed and the mean numbers of papillomas per mouse were approximately reduced by $33 \%$ and $36 \%$ in two groups treated with the triterpenes [25]. M. charantia seeds also exhibited strong inhibitory activity on tumor cells in vivo [146]. 
Research has demonstarted the effect on Su9T01, HUT-102 and Jurkat cells when compared with extracts of other plants, and the inhibitory effect on cell proliferation may partly be attributed to $\alpha$-eleostearic acid [147]. $\alpha$-eleostearic acid, which is known as the major component in $M$. charantia seeds, as well as its dihydroxy derivative, has been proved to be the most effective antitumor agent extracted by ethanol; it strongly inhibited the growth of some cancer and fibroblast cell lines, including those of HL60 leukemia and HT29 colon carcinoma [148]. Eleostearic acid inhibited the proliferation of both breast cancer cell lines of estrogen receptor (ER) $\alpha$-negative and ER $\alpha$-positive and induced G2-M block in the cell cycle and apoptosis [149].

Matrix metalloproteinases (MMPs) play an important role in the degradation of the extracellular matrix and are closely associated with the occurrence and promotion of many diseases, such as tumor invasion, metastasis and neovascularization in pathological cases. Therefore, blocking the degradation of extracellular matrix and inhibiting the activity of MMPs has gradually become a new target for tumor therapy [150]. Studies found that ethanol extracts of bitter gourd leaves can significantly reduce the transfer and invasion of prostate cells in vitro by depressing the secretion of MMP-2 and MMP-9 [151]. Its methanolic extracts inhibited the motility of human lung adenocarcinoma CL1 series of cell lines in a dose-dependent manner and depressed the activity of enzymes related to metastases. For CL1-0 and CL1-5, methanolic extract inhibited Src and FAK to varying degrees, which play an important role in the process of tumor invasion to malignant invasion phenotype [152].

M. charantia juice activated AMPKs in human pancreatic carcinoma cells, decreased cell viability in all four pancreatic carcinoma cell lines (BxPC-3, MiaPaCa-2, AsPC-1 and Capan-2 cells), exerted strong apoptosis-inducing activity and significantly inhibited MiaPaCa-2 tumor xenograft growth without noticeable toxicity in nude mice [153]. Prostate cancer cells (human prostate cancer cells, PC3 and LNCaP) treated with $M$. charantia extracts accumulated S phase cell populations, modulated cyclin D1, cyclin E, and p21 expression, enhanced Bax expression, induced PARP cleavage and delayed the progression to high-grade prostatic intraepithelial neoplasia in TRAMP (transgenic adenocarcinoma of mouse prostate) mice [154]. The inhibition effect was not due to a cytotoxic effects of the M. charantia aqueous extract but rather to blocking the growth of prostate adenocarcinoma cells and decreasing the basal level of cyclic GMP in vitro and in vivo [155]. MAP30 recombinant protein, which was expressed by E. coli BL21 (DE3) cells, inhibited the growth of bladder cancer 5637 cells by inducing apoptosis in a dose- and time-dependent manner at 100, 200 and $400 \mu \mathrm{g} / \mathrm{mL}$ [156]. RNase MC2 isolated from $M$. charantia has been found to inhibit the proliferation of Hep G2, lead to cell cycle arrest and apoptosis [157]. Treatment of MCF-7 cells with RNase MC2 caused nuclear damage and finally resulted in early/late apoptosis, and early apoptosis was induced in a dose-escalating manner after exposure to increasing concentrations of RNase MC2 [158].

GADD45 was identified to be a critical mediator of apoptosis triggered by the activation of JNK and/or p38, via MTK1/MEKK4 MAPK signaling pathways [159]. M. charantia seed oil treatment upregulated GADD45, p53 and PPAR $\gamma$ mRNA expression, and thereby induced apoptosis in Caco-2 cells, and acted better than troglitazone at $25 \mu \mathrm{M}$ [160]. As for the azoxymethane (AOM)-induced colonic aberrant crypt foci model, dietary supplementation with seed oil from $M$. charantia enhanced expression of PPAR protein levels and significantly reduce the incidence and the multiplicity of tumors [161]. Although the mechanism of how AMPK activation plays a role in tumor cells has not been fully understood yet, Kwatra et al. [162] found that methanol extract of M. charantia fruit can activate AMPK by reducing intracellular ATP levels, leading to tumor cell autophagy of colon cancer stem cells and ancestral cells.

P-glycoprotein (P-gp) is a transmembrane glycoprotein with a Mw of $170 \mathrm{kD}(\mathrm{P} 170)$, which acts as an energy-dependent "drug pump"; it reduces intracellular drug concentration and is associated with multi-drug resistance [163]. M. charantia leaf extract was able to reverse the MDR phenotype by increasing the intracellular accumulation of chemotherapeutic drugs [164].

Bitter melon extract induced a significant decrease in the cell viability ( $>80 \%)$ of MDA-MB-231 and MCF-7 cells at concentrations of $2 \%$ and $5 \%$ while cytotoxicity on primary epithelial cells was 
negligible; it induces PARP cleavage and caspases activation in MCF-7 cells and the inhibition of apoptotic signaling proteins (survivin, XIAP and claspin) in both cell lines. Moreover, the expression of anti-apoptotic proteins was different, which lead to the conclusion that several signaling pathways are involved in breast cancer cell death [165]. Cell growth of LNCaP was significantly inhibited by $M$. charantia leaf extract through arresting cells in the G1 phase; the extract also inhibited the expression of cyclin D1, PCNA and Bcl-2, and increased cleaved caspase-3 [166]. M. charantia can depress cancer cells proliferation in experimental settings; its antitumor activities may be partially attributed to MAP30, $\alpha-\mathrm{MMC}, \beta-\mathrm{MMC}$ and other medicinal proteins. In summary, bioactive components of $M$. charantia act as anti-tumor agents mainly through inhibiting tumor cell proliferation, inducing tumor cell apoptosis, influencing energy metabolism, depressing tumor cell metastasis and enhancing the relevant tumor suppressor gene activity (Table 2). 
Table 2. Suppressing effect on tumor cells of M. charantia constituents.

\begin{tabular}{|c|c|c|c|c|c|}
\hline Manifestations & Constituent(s) & Cell Type & Relevant Markers & $\begin{array}{c}\text { Mechanisms/Relevant } \\
\text { Pathways }\end{array}$ & Reference \\
\hline Antiprolifer-ative effect & M. charantia seed extract & $\begin{array}{l}\text { Su9T01, HUT-102, } \\
\text { Jurkat cells }\end{array}$ & IC50 & - & [147] \\
\hline \multirow{2}{*}{ Induce apoptosis } & MAP30 & Hep G2 & $\begin{array}{l}\text { p53, PARP, Bcl2, Bak, JC-1, } \\
\text { Bid, caspase-3, } 8,9\end{array}$ & $\begin{array}{c}\text { Act through extrinsic and } \\
\text { intrinsic caspase } \\
\text { pathways }\end{array}$ & \multirow{2}{*}[38,157]{} \\
\hline & $\begin{array}{l}\text { 3ß,7 } \beta \text {-dihydroxy-25-methoxycucurbita- } \\
\text { 5,23-diene-19-al (DMC) }\end{array}$ & $\begin{array}{l}\text { a- (LK) B1-deficient } \\
\text { MDA-MB-231 }\end{array}$ & $\begin{array}{c}\text { Cyclin D1, CDK6, Bcl-2, } \\
\text { XIAP, cyclooxygenase-2, } \\
\text { NF-кB }\end{array}$ & $\begin{array}{c}\text { PPAR } \gamma \text {-targeted signaling } \\
\text { pathways }\end{array}$ & \\
\hline \multirow{3}{*}{$\begin{array}{l}\text { Influence energy } \\
\text { metabolism }\end{array}$} & Bitter melon juice & $\begin{array}{l}\text { BxPC-3, MiaPaCa-2, } \\
\text { AsPC-1, Capan-2 }\end{array}$ & $\begin{array}{c}\text { Caspases, Bcl-2, } \\
\text { cytochrome c, survivin, } \\
\text { p21, phosphorylated } \\
\text { MAPKs }\end{array}$ & MAPK pathway & \multirow{3}{*}[153,154,167]{} \\
\hline & $\begin{array}{l}\text { Methanol extract of } M \text {. charantia } \\
\text { (MCME) }\end{array}$ & $\begin{array}{l}\text { Hone-1, AGS, HCT-116, } \\
\text { CL1-0 }\end{array}$ & $\begin{array}{c}\text { caspase-3, DFF45, PARP, } \\
\text { Bax, Bcl-2 }\end{array}$ & $\begin{array}{c}\text { Caspase- and } \\
\text { mitochondria-dependent } \\
\text { pathways }\end{array}$ & \\
\hline & Bitter melon extract (BME) & PC3, LNCaP & $\begin{array}{l}\text { Cyclin D1, cyclin E, p21, } \\
\text { Bax }\end{array}$ & $\begin{array}{l}\text { MEK-ERK and p38 } \\
\text { MAPK pathway }\end{array}$ & \\
\hline \multirow{3}{*}{$\begin{array}{l}\text { Depress tumor cell } \\
\text { metastasis }\end{array}$} & Kuguacin J & PC3 & \multirow{2}{*}{ MMP-2, MMP-9, uPA } & \multirow{3}{*}{$\begin{array}{c}\text { Inhibition of the } \\
\text { expression of Akt, } \\
\beta \text {-catenin, and MMPs }\end{array}$} & \multirow{3}{*}[151,152,168]{} \\
\hline & M. charantia leaf extracts (BMLE) & PLS10 & & & \\
\hline & MCME & CL1-0, CL1-5 & MMP-2, MMP-9, Src, FAK & & \\
\hline Reverse MDR & M. charantia leaf extracts & KB-V1 & Resistance to vinblastine & $\begin{array}{c}\text { Inhibition of } \\
\text { P-glycoprotein activity }\end{array}$ & [164] \\
\hline
\end{tabular}




\subsection{Hypolipidemic Activity}

In experimental groups, rats were fed with M. charantia at a dose of $140 \mathrm{mg} / \mathrm{kg}$ for 30 days, the levels of cholesterol on day 10 were slightly reduced, and a slow reduction was noted in the level of triglycerides after 20 days; supplementation of $M$. charantia significantly decreased the rate of changes in the level of high-density lipoprotein-cholesterol (HDL) and low-density lipoprotein-cholesterol (LDL) $(p<0.001)$ [105]. The BMSO (bitter melon seed oil) has been proven to have weight-reducing capability $(10 \mathrm{~g} / \mathrm{kg})$ in animal experimentation; the indices approached normal control from week 21, and high dose BMSO normalized serum free fatty acid levels in HFD mice after administration; histological changes were also observed as decreased size of adipose cells [169].

Non-esterified cholesterol levels as well as phospholipids were two-times those in the control group in diabetes rats induced by STZ; triglyceride (TG) levels in the experimental group were four-times those in the control group; high-density lipoprotein-cholesterol (HDL-c) levels were 50\% of those in the control group. Data evidence suggest that $M$. charantia had an effect in rat serum after 14 days of feeding with $0.5 \%, 1 \%$ and $3 \%$ dried powder. Both redced non-esterified cholesterol, cholesterol and TG contents back to normal levels after treatment in a dose-dependent manner. The experiment also found that TG levels in STZ-induced diabetic rat livers and kidneys decreased compared to the normal control group, the phenomenon demonstrated that lipid fluidity was increased or uptake and storage capacity of free fatty acids was decreased in these tissues, thereby causing the serum TG and phospholipid increase [170]. Dietary administration of M. charantia consistently elevated HDL-cholesterol levels. Differences in serum lipid parameters (triglyceride, total cholesterol and phospholipid) were demonstrated to be negligible in rats fed the cholesterol-free diet and groups fed with different doses of $M$. charantia unripe fruit powder [170]. After supplemention of $M$. charantia $(1.5 \%)$, rats in experimental groups showed lower energy efficiency, visceral fat mass, plasma glucose and hepatic triacylglycerol, but higher serum free fatty acids and plasma catecholamines from the fourth week; plasma epinephrine was elevated at seven weeks while steatosis score decreased with a statistically significant difference from the control [171]. For diet-induced obese (DIO) rats, activities of hepatic and soleus muscle mitochondrial carnitine palmitoyl transferase-I (CPT-I) and acyl-CoA dehydrogenase (AD) are elevated; serum adiponectin, uncoupling protein 1 in brown adipose tissue, uncoupling protein 3 in red gastrocnemius muscle and transcription coactivator PGC- $1 \alpha$ in both tissues were also significantly elevated after $M$. charantia supplementation [172].

Triterpenoid extracts of $M$. charantia were used for treatment of 3T3-L1 cells. Preadipocyte viability with increasing concentrations (with the exception of concentrations between 0.25 and $0.30 \mathrm{mg} / \mathrm{mL}$ ) decreased significantly; increasing levels of lactate dehydrogenase indicate that the extract could destroy the integrity of cell membranes. It also led to G2/M block after 48 and $72 \mathrm{~h}$ of treatment, and down-regulated PPAR- $\gamma$ and adiponectin [173].

The potential of $M$. charantia on lowering hepatic triglyceride and cholesterol concentration is mainly attributed to active component(s) in methanolic extracts [174]. The mechanism of steryl glycoside fraction of $M$. charantia inhibits lipid metabolism in vivo lies in the noncompetitive inhibitory effect on corticotropin, glucagon and epinephrine-induced lipolysis by isolated rat adipocytes [53].

\subsection{Immunomodulatory Activity}

M. charantia methanolic extracts can significantly promote the secretion of $\mathrm{NO}$ and phagocytic activity evaluated via carbon clearance assays in in vivo studies [175]. A water-soluble polysaccharide activated macrophages, splenocytes and thymocytes in vitro, with a maximum effect on NO production and SPI index at a concentration of $200 \mu \mathrm{g} / \mathrm{mL}$, while the most effective dose to stimulate splenocytes was observed at $25 \mu \mathrm{g} / \mathrm{mL}$ [63].

Studies have shown that after two days of incubation with a dose of $100 \mu \mathrm{g} / \mathrm{mL}, \alpha$ - and $\beta$-momordicin have almost no cytotoxic effects on normal cells [41]; the substances have been proven to play an immunomodulatory role by inhibiting the activity of lymphocytes or shifting the kinetic parameters of immune responses [124]; they significantly inhibited mitogenic responses present in 
mice spleen cells due to the lectin, concanavalin A and the lipopolysaccharides. Momordicin activates and promotes $B$ cell proliferation by inducing surface membrane immunoglobulin activity, while increasing B cell subsets CD86 (cell activation target point) expression, which plays a major role in humoral immunity. In addition, it can induce spleen cells to secrete large amounts of non-specific immunoglobulin IgM after $96 \mathrm{~h}$ co-culture and play a role in immune regulation [176]. In vitro, saponins isolated from $M$. charantia may promote IL-2 secretion by varying the ratio of $\mathrm{T}$ cells, enhancing phagocytic activity and improving immune function in aging mice [177].

\subsection{Wound Healing Activity}

A series of abnormalities such as impaired immune response and neovascularization, growth factor deficiencies and decreased synthesis of collagen are associated with diabetes and to the delayed wound healing [178]. Treatment with $M$. charantia fruit ointment could significantly enhance wound closure in diabetic rats, and upregulate TGF- $\beta$ expression in wound tissue, which plays an important role in regulating cell growth and differentiation [179]. For normal experimental animals, methanol extracts also had a similar efficacy and significantly reduced wound area and period of epithelisation [180].

\subsection{Others}

There are also some reports on other bioactivities. Components in M. charantia have an inhibitory effect on gastroinstestinal nematodes [181]. Momordin was reported to have hypotensive effects [182]. Administration of ethanolic extracts $(500 \mathrm{mg} / \mathrm{kg}$ ) significantly reduced acetic acid-induced writhing and yeast-induced fever [183]. A fruit extract has been demonstrated to possess activity against Helicobacter pylori, which could induce stomach ulcers [184]. Dry powder and volatile oil components of $M$. charantia exhibit strong inhibition on mice skin ulcers induced by alcohol in a dose-dependent manner [185].

\section{Toxicity and Side Effects}

Although the plant is basically harmless to human body under normal conditions, it may induce adverse reactions according to different uptakes, processing methods, physical differences and other conditions. There have been reports of toxicity since 1960s, mainly including acute toxicity, chronic toxicity and reproductive toxicity.

Monthly intake of M. charantia leaves was used to prevent childbirth in India [186]. The ethanolic extract of M. charantia Linn seed have a greater impact on spermatogenesis and induced histological changes in both testis and accessory reproductive organs of albino mice [187]. For female Wistar rats, aqueous leaf extracts decreased plasma progesterone and estrogen levels in a dose-dependent manner in comparison to the controls [188]. RIPs were also found to have antifertility activity [189]. $\alpha$-MMC could induce termination of early pregnancy and cause abortion; the probable explanation is the inhibition on development of morulae [190]; $\beta$-MMC was also demonstrated to have similar effects, not only influencing embryo adhesion and implantation but also depressing the growth of embryos [191].

Subcutaneous injection of alcoholic extracts mainly induced acute symptoms such as changes in respiratory and heart rates; anatomic results also suggest it led to pathological changes in these organs, and $M$. charantia juice showed a much stronger effect with $\mathrm{LC}_{50}=91.9 \mathrm{mg} / 100 \mathrm{~g}$ body weight (b.wt.), compared to alcoholic extracts of $362.34 \mathrm{mg} / 100 \mathrm{~g}$ b.wt [192]. Related research is mainly about the toxicity of subcutaneous injection and reports on oral toxicity are relatively rare. Clinical studies demonstrated that high-dose ingestion (equivalent to 250-500 g) of $M$. charantia fruit caused abdominal pain and diarrhea in diabetes [193]. Moreover, the aqueous extract was reported to significantly decrease hemoglobin concentration of albino rats [194]. M. charantia lectin had a cytotoxic effect, which significantly inhibited DNA and protein synthesis in human peripheral blood lymphocytes of normal 
or leukaemic cells [195]. At the cellular level, 500 and $600 \mu \mathrm{g} / \mathrm{mL}$ TPE was also reported to be toxic to keratinocytes and fibroblasts in vitro [121].

\section{Conclusions}

Up to now, research on the bioactivities of $M$. charantia has developed rapidly. The separation and identification of bioactive components from the plant have attracted more attention, and still maintain an upward trend, while mechanisms in many of the studies still remain to be developed. Clinical studies of the components, especially polysaccharides, should be the focus of research in the long term. With much further research on bitter gourd, the relationship between structure and mechanisms of the efficacy of the various functional constituents will be clarified. At the same time, potential adverse effects should also be investigated further. Firstly, the possible side-effects on the human body, especially long-term consumption, have not been studied. Then, intake of $M$. charantia may also increase the risk of hypoglycemia in diabetic patients. For special populations, taking $M$. charantia should follow the recommendations of doctors or experts. Last but not least, the vast majority of existing studies on bioactive components are performed at the animal and cell levels, hence, their impact on humans has not been demonstrated yet. Therefore, clinical research is needed before their application in relevant industries.

Application of bitter melon in food and pharmaceutical fields are still in the initial processing stages; the health benefits are still far from being fully utilized. Because of its numerous health functions, the plant can be utilized in lowering blood glucose, in tumor therapy and other aspects of clinical applications with broad prospects under the premise of ensuring safety.

Acknowledgments: The authors gratefully acknowledge the financial supports by the Natural Science Fund for Distinguished Young Scholars of Jiangxi Province, China (No. 20171BCB23022).

Author Contributions: Jianhua Xie conceived the work and approved the final version; Shuo Jia drafted the manuscript; Mingyue Shen and Fan Zhang revised the paper.

Conflicts of Interest: The authors declare no conflict of interest.

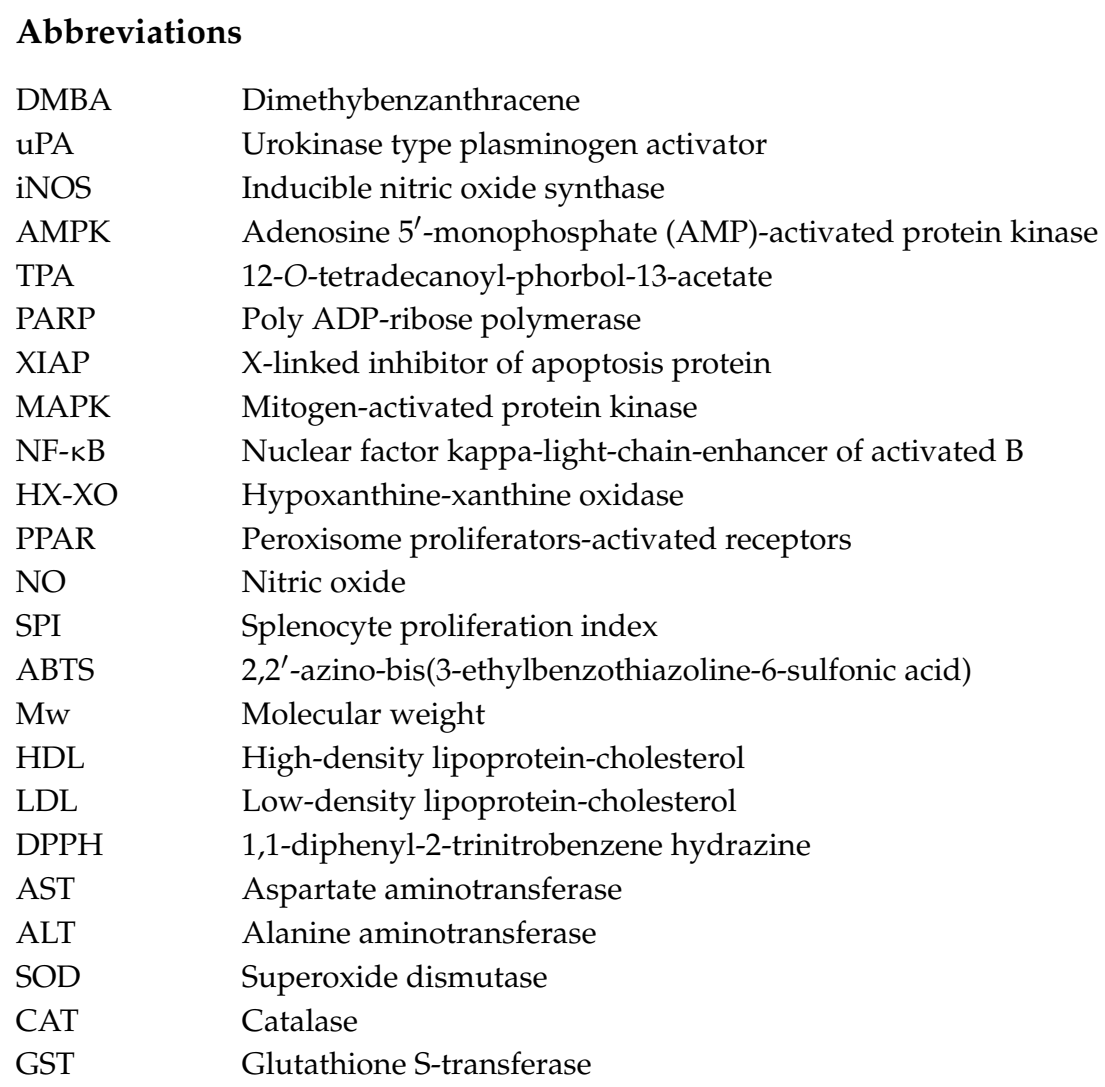




\section{References}

1. Habicht, S.D.; Kind, V.; Rudloff, S.; Borsch, C.; Mueller, A.S.; Pallauf, J.; Yang, R.Y.; Krawinkel, M.B. Quantification of antidiabetic extracts and compounds in bitter gourd varieties. Food Chem. 2011, 126, 172-176. [CrossRef]

2. Subratty, A.H.; Gurib-Fakim, A.; Mahomoodally, F. Bitter melon: An exotic vegetable with medicinal values. Nutr. Food Sci. 2005, 35, 143-147. [CrossRef]

3. Aminah, A.; Anna, P.K. Influence of ripening stages on physicochemical characteristics and antioxidant properties of bitter gourd (Momordica charantia). Int. Food Res. J. 2011, 18, 895-900.

4. Walters, T.W.; Decker-Walters, D.S. Balsam-pear (Momordica charantia, Cucurbitaceae). Econ. Bot. 1988, 42, 286-288.

5. Shan, B.; Xie, J.H.; Zhu, J.H.; Peng, Y. Ethanol modified supercritical carbon dioxide extraction of flavonoids from Momordica charantia L. and its antioxidant activity. Food Bioprod. Process. 2012, 90, 579-587. [CrossRef]

6. Grover, J.K.; Yadav, S.P. Pharmacological actions and potential uses of Momordica charantia: A review. J. Ethnopharmacol. 2004, 93, 123-132. [CrossRef] [PubMed]

7. Prasad, V.; Jain, V.; Girish, D.; Dorle, A.K. Wound-healing property of Momordica charantia L. fruit powder. J. Hreb. Pharmacother. 2006, 6, 105-115. [CrossRef]

8. Raman, A.; Lau, C. Anti-diabetic properties and phytochemistry of Momordica charantia L. (Cucurbitaceae). Phytomedicine 1996, 2, 349-362. [CrossRef]

9. Virdi, J.; Sivakami, S.; Shahani, S.; Suthar, A.C.; Banavalikar, M.M.; Biyani, M.K. Antihyperglycemic effects of three extracts from Momordica charantia. J. Ethnopharmacol. 2003, 88, 107-111. [CrossRef]

10. Bailey, C.J.; Day, C.; Leatherdale, B.A. Traditional treatments for diabetes from Asia and the West Indies. Pract. Diabetes 1986, 3, 190-192. [CrossRef]

11. Dans, A.M.L.; Villarruz, M.V.C.; Jimeno, C.A.; Javelosa, M.A.U.; Chua, J.; Bautista, R.; Velez, G.G.B. The effect of Momordica charantia capsule preparation on glycemic control in type 2 diabetes mellitus needs further studies. J. Clin. Epidemiol. 2007, 60, 554-559. [CrossRef] [PubMed]

12. Ahmed, I.; Adeghate, E.; Sharma, A.K.; Pallot, D.J.; Singh, J. Effects of Momordica charantia fruit juice on islet morphology in the pancreas of the streptozotocin-diabetic rat. Diabetes Res. Clin. Pract. 1998, 40, 145-151. [CrossRef]

13. Matsuda, M.; DeFronzo, R.A. Insulin sensitivity indices obtained from oral glucose tolerance testing: Comparison with the euglycemic insulin clamp. Diabetes Care 1999, 22, 1462-1470. [CrossRef] [PubMed]

14. Raza, H.; Ahmed, I.; John, A.; Sharma, A.K. Modulation of xenobiotic metabolism and oxidative stress in chronic streptozotocin-induced diabetic rats fed with Momordica charantia fruit extract. J. Biochem. Mol. Toxicol. 2000, 14, 131-139. [CrossRef]

15. Saeed, S.; Tariq, P. Antibacterial activities of Mentha piperita, Pisum sativum and Momordica charantia. Pak. J. Bot. 2005, 37, 997.

16. Grover, J.K.; Yadav, S.; Vats, V. Medicinal plants of India with anti-diabetic potential. J. Ethnopharmacol. 2002, 81, 81-100. [CrossRef]

17. Teoh, S.L.; Latiff, A.A.; Das, S. The effect of topical extract of Momordica charantia (bitter gourd) on wound healing in nondiabetic rats and in rats with diabetes induced by streptozotocin. Clin. Exp. Dermatol. 2009, 34, 815-822. [CrossRef] [PubMed]

18. Liu, J.Q.; Chen, J.C.; Wang, C.F.; Qiu, M.H. New cucurbitane triterpenoids and steroidal glycoside from Momordica charantia. Molecules 2009, 14, 4804-4813. [CrossRef] [PubMed]

19. Najafi, P.; Torki, M. Performance, blood metabolites and immunocompetaence of broiler chicks fed diets included essential oils of medicinal herbs. J. Anim. Vet. Adv. 2010, 9, 1164-1168.

20. Ayeni, M.J.; Oyeyemi, S.D.; Kayode, J.; Peter, G.P. Phytochemical, proximate and mineral analyses of the leaves of Gossypium hirsutum L. and Momordica charantia L. J. Nat. Sci. Res. 2015, 5, 99-107.

21. Chen, J.; Tian, R.; Qiu, M.; Lu, L.; Zheng, Y.; Zhang, Z. Trinorcucurbitane and cucurbitane triterpenoids from the roots of Momordica charantia. Phytochemistry 2008, 69, 1043-1048. [CrossRef] [PubMed]

22. Zhao, G.T.; Liu, J.Q.; Deng, Y.Y.; Li, H.Z.; Chen, J.C.; Zhang, Z.R.; Qiu, M.H. Cucurbitane-type triterpenoids from the stems and leaves of Momordica charantia. Fitoterapia 2014, 95, 75-82. [CrossRef] [PubMed]

23. Chang, C.I.; Chen, C.R.; Liao, Y.W.; Cheng, H.L.; Chen, Y.C.; Chou, C.H. Cucurbitane-type triterpenoids from the stems of Momordica charantia. J. Nat. Prod. 2008, 71, 1327-1330. [CrossRef] [PubMed] 
24. Begum, S.; Ahmed, M.; Siddiqui, B.S.; Khan, A.; Saify, Z.S.; Arif, M. Triterpenes, a sterol and a monocyclic alcohol from Momordica charantia. Phytochemistry 1997, 44, 1313-1320. [CrossRef]

25. Akihisa, T.; Higo, N.; Tokuda, H.; Ukiya, M.; Akazawa, H.; Tochigi, Y.; Nishino, H. Cucurbitane-type triterpenoids from the fruits of Momordica charantia and their cancer chemopreventive effects. J. Nat. Prod. 2007, 70, 1233-1239. [CrossRef] [PubMed]

26. Ma, L.; Yu, A.H.; Sun, L.L.; Gao, W.; Zhang, M.M.; Su, Y.L.; Liu, H.; Ji, T. Two new bidesmoside triterpenoid saponins from the seeds of Momordica charantia L. Molecules 2014, 19, 2238-2246. [CrossRef] [PubMed]

27. Murakami, T.; Emoto, A.; Matsuda, H.; Yoshikawa, M. Medicinal foodstuffs. XXI. Structures of new cucurbitane-type triterpene glycosides, goyaglycosides-a,-b,-c,-d,-e,-f,-g, and-h, and new oleanane-type triterpene saponins, goyasaponins I, II, and III, from the fresh fruit of Japanese Momordica charantia L. Chem. Pharm. Bull. 2001, 49, 54-63. [CrossRef] [PubMed]

28. Ahmad, Z.; Zamhuri, K.F.; Yaacob, A.; Siong, C.H.; Selvarajah, M.; Ismail, A.; Hakim, M.N. In vitro anti-diabetic activities and chemical analysis of polypeptide-k and oil isolated from seeds of Momordica charantia (bitter gourd). Molecules 2012, 17, 9631-9640. [CrossRef] [PubMed]

29. Wen, L.J.; Liu, W.F. Study on extracting and antioxidant activity of flavonoids from Momordica charantia L. Food Sci. 2007, 9, 042.

30. Okabe, H.; Miyahara, Y.; Yamauchi, T.; Miyahara, K.; Kawasaki, T. Studies on the constituents of Momordica charantia LI Isolation and characterization of momordicosides A and B, glycosides of a pentahydroxy-cucurbitane triterpene. Chem. Pharm. Bull. 1980, 28, 2753-2762. [CrossRef]

31. Xu, X.; Shan, B.; Liao, C.H.; Xie, J.H.; Wen, P.W.; Shi, J.Y. Anti-diabetic properties of Momordica charantia L. polysaccharide in alloxan-induced diabetic mice. Int. J. Biol. Macromol. 2015, 81, 538-543. [CrossRef] [PubMed]

32. Zhang, F.; Lin, L.; Xie, J. A mini-review of chemical and biological properties of polysaccharides from Momordica charantia. Int. J. Biol. Macromol. 2016, 92, 246-253. [CrossRef] [PubMed]

33. Deng, Y.Y.; Yi, Y.; Zhang, L.F.; Zhang, R.F.; Zhang, Y.; Wei, Z.C.; Zhang, M.W. Immunomodulatory activity and partial characterization of polysaccharides from Momordica charantia. Molecules 2014, 19, 13432-13447. [CrossRef] [PubMed]

34. Duan, Z.Z.; Zhou, X.L.; Li, Y.H.; Zhang, F.; Li, F.Y.; Su-Hua, Q. Protection of Momordica charantia polysaccharide against intracerebral hemorrhage-induced brain injury through JNK3 signaling pathway. J. Recept. Signal Transduct. 2015, 35, 523-529. [CrossRef] [PubMed]

35. Cai, Y.; Liu, M.; Wu, X.; Wang, Z.; Liang, C.; Yang, Y. Study on the antitumor and immune-stimulating activity of polysaccharide from Momordica charantia. Pharm. Clin. Res. 2010, 18, 131-134.

36. Zhang, P.P.; Liu, J.F.; Wang, C.L.; Ye, Y.T.; Xie, J.H. Study on the antimicrobial activities of the extracts from Momordica charantia L. Nat. Prod. Res. 2008, 20, 721-724. [CrossRef]

37. Puri, M.; Kaur, I.; Kanwar, R.K.; Gupta, R.C.; Chauhan, A.; Kanwar, J.R. Ribosome inactivating proteins (RIPs) from Momordica charantia for anti viral therapy. Curr. Mol. Med. 2009, 9, 1080-1094. [CrossRef] [PubMed]

38. Fang, E.F.; Zhang, C.Z.Y.; Wong, J.H.; Shen, J.Y.; Li, C.H.; Ng, T.B. The MAP30 protein from bitter gourd (Momordica charantia) seeds promotes apoptosis in liver cancer cells in vitro and in vivo. Cancer. Lett. 2012, 324, 66-74. [CrossRef] [PubMed]

39. Pu, Z.; Lu, B.Y.; Liu, W.Y.; Jin, S.W. Characterization of the enzymatic mechanism of $\gamma$-momorcharin, a novel ribosome-inactivating protein with lower molecular weight of 11,500 purified from the seeds of bitter gourd (Momordica charantia). Biochem. Biophys. Res. Commun. 1996, 229, 287-294. [CrossRef] [PubMed]

40. Meng, Y.; Liu, S.; Li, J.; Meng, Y.; Zhao, X. Preparation of an antitumor and antivirus agent: Chemical modification of $\alpha$-MMC and MAP30 from Momordica charantia L. with covalent conjugation of polyethyelene glycol. Int. J. Nanomed. 2012, 7, 3133.

41. Leung, S.O.; Yeung, H.W.; Leung, K.N. The immunosuppressive activities of two abortifacient proteins isolated from the seeds of bitter melon (Momordica charantia). Immunopharmarcology 1987, 13, 159-171. [CrossRef]

42. Jabeen, U.; Khanum, A. Isolation and characterization of potential food preservative peptide from Momordica charantia L. Arabian J. Chem. 2017, 10, S3982-S3989. [CrossRef] 
43. Fang, E.F.; Zhang, C.Z.Y.; Ng, T.B.; Wong, J.H.; Pan, W.L.; Ye, X.J.; Chan, Y.S.; Fong, W.P. Momordica charantia lectin, a type II ribosome inactivating protein, exhibits antitumor activity toward human nasopharyngeal carcinoma cells in vitro and in vivo. Cancer Prev. Res. 2012, 5, 109-121. [CrossRef] [PubMed]

44. Dhar, P.; Chattopadhyay, K.; Bhattacharyya, D.; Roychoudhury, A.; Biswas, A.; Ghosh, S. Antioxidative effect of conjugated linolenic acid in diabetic and non-diabetic blood: An in vitro study. J. Oleo Sci. 2007, 56, $19-24$. [CrossRef]

45. Tsuzuki, T.; Tokuyama, Y.; Igarashi, M.; Miyazawa, T. Tumor growth suppression by $\alpha$-eleostearic acid, a linolenic acid isomer with a conjugated triene system, via lipid peroxidation. Carcinogenesis 2004, 25, 1417-1425. [CrossRef] [PubMed]

46. Suzuki, R.; Arato, S.; Noguchi, R.; Miyashita, K.; Tachikawa, O. Occurrence of conjugated linolenic acid in flesh and seed of bitter gourd. J. Oleo Sci. 2001, 50, 753-758. [CrossRef]

47. Agrawal, R.C.; Beohar, T. Chemopreventive and anticarcinogenic effects of Momordica charantia extract. Asian Pac. J. Cancer Prev. 2010, 11, 371-375. [PubMed]

48. Liu, C.H.; Yen, M.H.; Tsang, S.F.; Gan, K.H.; Hsu, H.Y.; Lin, C.N. Antioxidant triterpenoids from the stems of Momordica charantia. Food Chem. 2010, 118, 751-756. [CrossRef]

49. Chou, C.H.; Liao, M.H.; Chen, T.M.; Cheng, C.H.; Anggriani, R.; Tsai, C.P.; Tseng, H.I.; Cheng, H.L. Bitter melon triterpenes work as insulin sensitizers and insulin substitutes in insulin-resistant cells. J. Funct. Foods 2015, 13, 214-224.

50. Hsiao, P.C.; Liaw, C.C.; Hwang, S.Y.; Cheng, H.L.; Zhang, L.J.; Shen, C.C.; Hsu, F.L.; Kuo, Y.H. Antiproliferative and hypoglycemic cucurbitane-type glycosides from the fruits of Momordica charantia. J. Agric. Food Chem. 2013, 61, 2979-2986. [CrossRef] [PubMed]

51. Han, C.; Hui, Q.; Wang, Y. Hypoglycaemic activity of saponin fraction extracted from Momordica charantia in PEG/salt aqueous two-phase systems. Nat. Prod. Res. 2008, 22, 1112-1119. [CrossRef] [PubMed]

52. Keller, A.C.; Ma, J.; Kavalier, A.; He, K.; Brillantes, A.M.B.; Kennelly, E.J. Saponins from the traditional medicinal plant Momordica charantia stimulate insulin secretion in vitro. Phytomedicine 2011, 19, 32-37. [CrossRef] [PubMed]

53. Ng, T.B.; Wong, C.M.; Li, W.W.; Yeung, H.W. A steryl glycoside fraction from Momordica charantia seeds with an inhibitory action on lipid metabolism in vitro. Biochem. Cell Biol. 1986, 64, 766-771. [CrossRef] [PubMed]

54. Xia, K.; Yan, F.; Ye, Y.; Tang, L. The effect of the total saponin extract from the seeds of Momordica charantia L. on anti-virus HSV-I and RSV activity. J. Sichuan Univ. 2007, 1. [CrossRef]

55. Chang, L.Y.; Tang, L.; Yan, F.; Wang, S.; Chen, F. The Effect of the Total Saponin Extract from the Shoots of Momordica charantia L. on Anti-virus HSV-II Activity. J. Sichuan Univ. 2004, 3, 043.

56. Zhang, L.Y.; Wang, Y.T.; Geng, L.J. Bacteriostatic Activity of Total Saponins fromBalsam Pear (Momordica charantia) against Staphylococcus aureus. J. Microbiol. 2011, 1, 012.

57. Patel, T.; Parmar, K.; Bhatt, Y.; Patel, Y.; Patel, N.M. Isolation, characterization and antimicrobial activity of charantin from Momordica charantia linn. Fruit. Pharm. Clin. Res. 2010, 2, 629-634.

58. Anila, L.; Vijayalakshmi, N.R. Beneficial effects of flavonoids from Sesamum indicum, Emblica officinalis and Momordica charantia. Phytother. Res. 2000, 14, 592-595. [CrossRef]

59. Qader, S.W.; Abdulla, M.A.; Chua, L.S.; Najim, N.; Zain, M.M.; Hamdan, S. Antioxidant, total phenolic content and cytotoxicity evaluation of selected Malaysian plants. Molecules 2011, 16, 3433-3443. [CrossRef] [PubMed]

60. Bajpai, M.; Pande, A.; Tewari, S.K.; Prakash, D. Phenolic contents and antioxidant activity of some food and medicinal plants. Int. J. Food Sci. Nutr. 2005, 56, 287-291. [CrossRef] [PubMed]

61. Lin, J.Y.; Tang, C.Y. Determination of total phenolic and flavonoid contents in selected fruits and vegetables, as well as their stimulatory effects on mouse splenocyte proliferation. Food Chem. 2007, 101, 140-147. [CrossRef]

62. Guevara, A.P.; Lim-Sylianco, C.Y.; Dayrit, F.M.; Finch, P. Acylglucosyl sterols from Momordica charantia. Phytochemistry 1989, 28, 1721-1724. [CrossRef]

63. Panda, B.C.; Mondal, S.; Devi, K.S.P.; Maiti, T.K.; Khatua, S.; Acharya, K.; Islam, S.S. Pectic polysaccharide from the green fruits of Momordica charantia (Karela): Structural characterization and study of immunoenhancing and antioxidant properties. Carbohydr. Res. 2015, 401, 24-31. [CrossRef] [PubMed] 
64. Fan, T.; Hu, J.; Fu, L.; Zhang, L. Optimization of enzymolysis-ultrasonic assisted extraction of polysaccharides from Momordica charantia L. by response surface methodology. Carbohydr. Polym. 2015, 115, 701-706. [CrossRef] [PubMed]

65. Shao, P.; Zhang, J.F.; Chen, X.X.; Sun, P.L. Microwave-assisted extraction and purification of chlorogenic acid from by-products of Eucommia Ulmoides Oliver and its potential anti-tumor activity. J. Food Sci. Technol. 2015, 52, 4925-4934. [CrossRef] [PubMed]

66. Dong, Y.; Xu, B.; Lu, Q.; Zha, Q. Studies on the Isolation, Purification and Composition of Momordica charantia L. Polysaccharide. Food Sci. 2005, 11, 023.

67. Deng, Y.; Zhang, M.; Liu, J.; Zhang, Y.; Zhang, R.; Wei, Z. Comparison of the content, antioxidant activity, and $\alpha$-glucosidase inhibitory effect of polysaccharides from Momordicacharantia L. species. Mod. Food Sci. Technol. 2014, 30, 102-108.

68. Tan, H.F.; Gan, C.Y. Polysaccharide with antioxidant, $\alpha$-amylase inhibitory and ACE inhibitory activities from Momordica charantia. Int. J. Biol. Macromol. 2016, 85, 487-496. [CrossRef] [PubMed]

69. Raish, M. Momordica charantia, polysaccharides ameliorate oxidative stress, hyperlipidemia, inflammation, and apoptosis during myocardial infarction by inhibiting the nf-kb signaling pathway. Int. J. Biol. Macromol. 2017, 97, 544-551. [CrossRef] [PubMed]

70. Kang, J.; Zeng, B.; Tang, S.; Wang, M.; Han, X.; Zhou, C.; Tan, Z. Effects of Momordica charantia polysaccharide on in vitro ruminal fermentation and cellulolytic bacteria. Ital. J. Anim. Sci. 2017, 16, 226-233. [CrossRef]

71. Peumans, W.J.; Hao, Q.; van Damme, E.J. Ribosome-inactivating proteins from plants: More than RNA N-glycosidases. FASEB J. 2001, 15, 1493-1506. [CrossRef] [PubMed]

72. Fang, E.F.; Ng, T.B. Bitter gourd (Momordica charantia) is a cornucopia of health: A review of its credited antidiabetic, anti-HIV, and antitumor properties. Curr. Mol. Med. 2011, 11, 417-436. [CrossRef] [PubMed]

73. Wang, H.; Ng, T.B. Ribosome inactivating protein and lectin from bitter melon (Momordica charantia) seeds: Sequence comparison with related proteins. Biochem. Biophys. Res. Commun. 1998, 253, 143-146. [CrossRef] [PubMed]

74. Yuan, X.; Gu, X.; Tang, J. Purification and characterisation of a hypoglycemic peptide from Momordica charantia L. Var. abbreviata Ser. Food Chem. 2008, 111, 415-420. [CrossRef] [PubMed]

75. Mahatmanto, T. Review seed biopharmaceutical cyclic peptides: From discovery to applications. Pept. Sci. 2015, 104, 804-814. [CrossRef] [PubMed]

76. Zhang, B.; Xie, C.; Wei, Y.; Li, J.; Yang, X. Purification and characterisation of an antifungal protein, $\mathrm{MCha}-\mathrm{Pr}$, from the intercellular fluid of bitter gourd (Momordica charantia) leaves. Protein Expr. Purif. 2015, 107, 43-49. [CrossRef] [PubMed]

77. Xu, B.; Dong, Y. Determination on total saponins of Momordica charantia L. by spectrophotometry. Food Sci. 2005, 10, 165-169.

78. Vincken, J.P.; Heng, L.; de Groot, A.; Gruppen, H. Saponins, classification and occurrence in the plant kingdom. Phytochemistry 2007, 68, 275-297. [CrossRef] [PubMed]

79. Chen, J.C.; Chiu, M.H.; Nie, R.L.; Cordell, G.A.; Qiu, S.X. Cucurbitacins and cucurbitane glycosides: Structures and biological activities. Nat. Prod. Rep. 2005, 22, 386-399. [CrossRef] [PubMed]

80. Harinantenaina, L.; Tanaka, M.; Takaoka, S.; Oda, M.; Mogami, O.; Uchida, M.; Asakawa, Y. Momordica charantia constituents and antidiabetic screening of the isolated major compounds. Chem. Pharm. Bull. 2006, 54, 1017-1021. [CrossRef] [PubMed]

81. Zhang, L.J.; Liaw, C.C.; Hsiao, P.C.; Huang, H.C.; Lin, M.J.; Lin, Z.H.; Kuo, Y.H. Cucurbitane-type glycosides from the fruits of Momordica charantia and their hypoglycaemic and cytotoxic activities. J. Funct. Foods 2014, 6, 564-574. [CrossRef]

82. Zhang, L.J.; Huang, H.T.; Liaw, C.C.; Huang, S.Y.; Lin, Z.H.; Kuo, Y.H. Cucurbitane-type triterpenes and glycoside from the rattan of wild Momordica charantia and their anti-inflammatory and cytotoxic activities. Planta Medica 2016, 81, S1-S381. [CrossRef]

83. Tan, S.P.; Stathopoulos, C.; Parks, S.; Roach, P. An optimised aqueous extract of phenolic compounds from bitter melon with high antioxidant capacity. Antioxidants 2014, 3, 814-829. [CrossRef] [PubMed]

84. Kenny, O.; Smyth, T.J.; Hewage, C.M.; Brunton, N.P. Antioxidant properties and quantitative UPLC-MS analysis of phenolic compounds from extracts of fenugreek (Trigonella foenum-graecum) seeds and bitter melon (Momordica charantia) fruit. Food Chem. 2013, 141, 4295-4302. [CrossRef] [PubMed] 
85. Horax, R.; Hettiarachchy, N.; Islam, S. Total Phenolic contents and phenolic acid constituents in 4 varieties of bitter melons (Momordica charantia) and antioxidant activities of their extracts. J. Food Sci. 2005, 70. [CrossRef]

86. Budrat, P.; Shotipruk, A. Enhanced recovery of phenolic compounds from bitter melon (Momordica charantia) by subcritical water extraction. Sep. Purif. Technol. 2009, 66, 125-129. [CrossRef]

87. Horax, R.; Hettiarachchy, N.; Chen, P. Extraction, quantification, and antioxidant activities of phenolics from pericarp and seeds of bitter melons (Momordica charantia) harvested at three maturity stages (immature, mature, and ripe). J. Agric. Food Chem. 2010, 58, 4428-4433. [CrossRef] [PubMed]

88. Kubola, J.; Siriamornpun, S. Phenolic contents and antioxidant activities of bitter gourd (Momordica charantia L.) leaf, stem and fruit fraction extracts in vitro. Food Chem. 2008, 110, 881-890. [CrossRef] [PubMed]

89. Chuang, C.Y.; Hsu, C.; Chao, C.Y.; Wein, Y.S.; Kuo, Y.H.; Huang, C.J. Fractionation and identification of 9c, 11t, 13t-conjugated linolenic acid as an activator of PPAR $\alpha$ in bitter gourd (Momordica charantia L.). J. Biomed. Sci. 2006, 13, 763-772. [CrossRef] [PubMed]

90. Krawinkel, M.B.; Keding, G.B. Bitter gourd (Momordica charantia): A dietary approach to hyperglycemia. Nutr. Rev. 2006, 64, 331-337. [CrossRef] [PubMed]

91. Lucas, E.A.; Dumancas, G.G.; Smith, B.J.; Clarke, S.L.; Arjmandi, B.H. Health benefits of bitter melon (Momordica charantia). Bioact. Foods Promot. Health 2010, 35, 525-549.

92. Yuwai, K.E.; Rao, K.S.; Kaluwin, C.; Jones, G.P.; Rivett, D.E. Chemical composition of Momordica charantia L. fruits. J. Agric. Food Chem. 1991, 39, 1762-1763. [CrossRef]

93. Sarkar, N.; Mukherjee, A.; Barik, A. Olfactory responses of Epilachna dodecastigma (Coleoptera: Coccinellidae) to long-chain fatty acids from Momordica charantia leaves. Arthropod-Plant Interact. 2013, 7, 339-348. [CrossRef]

94. Ke, L.J.; Lu, W.; Chang, J.L.; Yuan, F.Y.; Rao, P.F.; Zhou, J.W. Effects of heat drying process on amino acid content of Momordica charantia L. Amino Acids Biol. Resour. 2010, 32, 14-16.

95. Han, C.; Zuo, J.; Wang, Q.; Xu, L.; Wang, Z.; Dong, H.; Gao, L. Effects of 1-MCP on postharvest physiology and quality of bitter melon (Momordica charantia L.). Sci. Hortic-Ansterdam 2015, 182, 86-91. [CrossRef]

96. American Diabetes Association. Diagnosis and classification of diabetes mellitus. Diabetes Care 2010, 33, S62-S69.

97. Arafat, S.Y.; Nayeem, M.; Jahan, S.; Karim, Z.; Reza, H.M.; Hossain, M.H.; Alam, M.A. Ellagic acid rich Momordica charantia fruit pulp supplementation prevented oxidative stress, fibrosis and inflammation in liver of alloxan induced diabetic rats. Orient. Pharm. Exp. Med. 2016, 16, 267-278. [CrossRef]

98. Ahmed, I.; Lakhani, M.S.; Gillett, M.; John, A.; Raza, H. Hypotriglyceridemic and hypocholesterolemic effects of anti-diabetic Momordica charantia (karela) fruit extract in streptozotocin-induced diabetic rats. Diabetes Res. Clin. Pract. 2001, 51, 155-161. [CrossRef]

99. Czompa, A.; Gyongyosi, A.; Szoke, K.; Bak, I.; Csepanyi, E.; Haines, D.D.; Lekli, I. Effects of Momordica charantia (Bitter Melon) on Ischemic Diabetic Myocardium. Molecules 2017, 22, 488. [CrossRef] [PubMed]

100. Thent, Z.C.; Das, S.; Zaidun, N.H. Emerging Trends on Drug Delivery Strategy of Momordica charantia against Diabetes and its Complications. Curr. Drug Deliv. 2017, 14. [CrossRef]

101. Welihinda, J.; Karunanayake, E.H.; Sheriff, M.H.H.; Jayasinghe, K.S.A. Effect of Momordica charantia on the glucose tolerance in maturity onset. J. Ethnopharmacol. 1986. [CrossRef]

102. Day, C.; Cartwright, T.; Provost, J.; Bailey, C.J. Hypoglycaemic effect of Momordica charantia extracts. Planta Medica 1990, 56, 426-429. [CrossRef] [PubMed]

103. Chaturvedi, P.; George, S. Momordica charantia maintains normal glucose levels and lipid profiles and prevents oxidative stress in diabetic rats subjected to chronic sucrose load. J. Med. Food 2010, 13, 520-527. [CrossRef] [PubMed]

104. Tripathi, U.N.; Chandra, D. Anti-hyperglycemic and anti-oxidative effect of aqueous extract of Momordica charantia pulp and Trigonella foenum graecum seed in alloxan-induced diabetic rats. Indian J. Biochem. Biophys. 2010, 47, 227-233. [PubMed]

105. Chaturvedi, P. Role of Momordica charantia in maintaining the normal levels of lipids and glucose in diabetic rats fed a high-fat and low-carbohydrate diet. Br. J. Biomed. Sci. 2005, 62, 124-126. [CrossRef] [PubMed]

106. Wang, S.; Li, Z.; Yang, G.; Ho, C.T.; Li, S. Momordica charantia: A popular health-promoting vegetable with multifunctionality. Food Funct. 2017, 8, 1749-1762. [CrossRef] [PubMed] 
107. Mishra, A.; Gautam, S.; Pal, S.; Mishra, A.; Rawat, A.K.; Maurya, R.; Srivastava, A.K. Effect of Momordica charantia fruits on streptozotocin-induced diabetes mellitus and its associated complications. Int. J. Pharm. Pharm. Sci. 2015, 7, 356-363.

108. Çakici, Í.; Hurmoğlu, C.; Tunçtan, B.; Abacioğlu, N.; Kanzik, Í.; Sener, B. Hypoglycaemic effect of Momordica charantia extracts in normoglycaemic or cyproheptadine-induced hyperglycaemic mice. J. Ethnopharmacol. 1994, 44, 117-121. [CrossRef]

109. Xiang, L.W.; Huang, X.N.; Chen, L.M.; Rao, P.F.; Ke, L.J. The reparative effects of Momordica charantia Linn. extract on HIT-T15 pancreatic $\beta$-Cells. Asia Pac. J. Clin. Nutr. 2007, 16, 249-252. [PubMed]

110. Khanna, P.; Jain, S.C.; Panagariya, A.; Dixit, V.P. Hypoglycemic activity of polypeptide-p from a plant source. J. Nat. Prod. 1981, 44, 648-655. [CrossRef] [PubMed]

111. Chaturvedi, P.; George, S.; Milinganyo, M.; Tripathi, Y.B. Effect of Momordica charantia on lipid profile and oral glucose tolerance in diabetic rats. Phytother. Res. 2004, 18, 954-956. [CrossRef] [PubMed]

112. Reyes, B.A.S.; Bautista, N.D.; Tanquilut, N.C.; Anunciado, R.V.; Leung, A.B.; Sanchez, G.C.; Maeda, K.I. Anti-diabetic potentials of Momordica charantia and Andrographis paniculata and their effects on estrous cyclicity of alloxan-induced diabetic rats. J. Ethnopharmacol. 2006, 105, 196-200. [CrossRef] [PubMed]

113. Fernandes, N.P.; Lagishetty, C.V.; Panda, V.S.; Naik, S.R. An experimental evaluation of the antidiabetic and antilipidemic properties of a standardized Momordica charantia fruit extract. BMC Complement. Altern. Med. 2007, 7, 29. [CrossRef] [PubMed]

114. Thenmozhi, A.J.; Subramanian, P. Antioxidant potential of Momordica charantia in ammonium chloride-induced hyperammonemic rats. Evid. Based Complement. Altern. Med. 2011, 8, 1-7. [CrossRef] [PubMed]

115. Padmashree, A.; Sharma, G.K.; Semwal, A.D. Studies on the antioxygenic activity of bitter gourd (Momordica charantia) and its fractions using various in vitro models. J. Sci. Food Agric. 2011, 91, 776-782. [CrossRef] [PubMed]

116. Tripathi, U.N.; Chandra, D. The plant extracts of Momordica charantia and Trigonella foenum graecum have antioxidant and anti-hyperglycemic properties for cardiac tissue during diabetes mellitus. Oxid. Med. Cell. Longev. 2009, 2, 290-296. [CrossRef] [PubMed]

117. Wu, S.J.; Ng, L.T. Antioxidant and free radical scavenging activities of wild bitter melon (Momordica charantia Linn. var. abbreviata Ser.) in Taiwan. LWT-Food Sci. Technol. 2008, 41, 323-330. [CrossRef]

118. Deng, Y.; Tang, Q.; Zhang, Y.; Zhang, R.; Wei, Z.; Tang, X.; Zhang, M. Protective effect of Momordica charantia water extract against liver injury in restraint-stressed mice and the underlying mechanism. Food Nutr. Res. 2017, 61, 1348864. [CrossRef] [PubMed]

119. Xie, J.; Zhang, J. Study on Antioxidant Activity in Vitro of Different Polysaccharides from Momordica charantia. Guangzhou Chem. Ind. 2010, 5. [CrossRef]

120. Lin, K.W.; Yang, S.C.; Lin, C.N. Antioxidant constituents from the stems and fruits of Momordica charantia. Food Chem. 2011, 127, 609-614. [CrossRef] [PubMed]

121. Kumar, R.; Balaji, S.; Sripriya, R.; Nithya, N.; Uma, T.S.; Sehgal, P.K. In vitro evaluation of antioxidants of fruit extract of Momordica charantia L. on fibroblasts and keratinocytes. J. Agric. Food Chem. 2010, 58, 1518-1522. [CrossRef] [PubMed]

122. Beloin, N.; Gbeassor, M.; Akpagana, K.; Hudson, J.; de Soussa, K.; Koumaglo, K.; Arnason, J.T. Ethnomedicinal uses of Momordica charantia (Cucurbitaceae) in Togo and relation to its phytochemistry and biological activity. J. Ethnopharmacol. 2005, 96, 49-55. [CrossRef] [PubMed]

123. Upadhyay, A.; Agrahari, P.; Singh, D.K. A review on salient pharmacological features of Momordica charantia. Int. J. Pharmacol. 2015, 11, 405-413.

124. Basch, E.; Gabardi, S.; Ulbricht, C. Bitter melon (Momordica charantia): A review of efficacy and safety. Am. J. Health-Syst. Pharm. 2003, 60, 356. [PubMed]

125. Lee-Huang, S.; Huang, P.L.; Nara, P.L.; Chen, H.C.; Kung, H.F.; Huang, P. Map 30: A new inhibitor of hiv-1 infection and replication. FEBS Lett. 1990, 272, 12. [CrossRef]

126. Leehuang, S.; Huang, P.L.; Chen, H.C.; Huang, P.L.; Bourinbaiar, A.; Huang, H.I. Anti-hiv and anti-tumor activities of recombinant map30 from bitter melon. Gene 1995, 161, 151-156. [CrossRef]

127. Wang, H.X.; Ng, T.B. Studies on the anti-mitogenic, anti-phage and hypotensive effects of several ribosome inactivating proteins. Comp. Biochem. Phys. Part C 2001, 128, 359-366. [CrossRef] 
128. Tian, G.P.; Li, S.J.; Guo, Q. Protective effect of momordicin on coxsackievirus b3 infected rat cardiocyte. J. South China Univ. 2009, 5, 006.

129. Braca, A.; Siciliano, T.; D'Arrigo, M.; Germanò, M.P. Chemical composition and antimicrobial activity of Momordica charantia seed essential oil. Fitoterapia 2008, 79, 123-125. [CrossRef] [PubMed]

130. Mahmood, A. Isolation and characterization of antimicrobial activity conferring component(s) from seeds of bitter gourd (Momordica charantia). J. Med. Plants Res. 2012, 6. [CrossRef]

131. Mada, S.B.; Garba, A.; Mohammed, H.A.; Muhammad, A.; Olagunju, A.; Muhammad, A.B. Antimicrobial activity and phytochemical screening of aqueous and ethanol extracts of Momordica charantia L. leaves. J. Med. Plants Res. 2013, 7, 579-586.

132. Costa, J.G.M.; Nascimento, E.M.M.; Campos, A.R.; Rodrigues, F.F.G. Antibacterial activity of Momordica charantia (curcubitaceae) extracts and fractions. J. Basic Clin. Pharm. 2011, 2, 45.

133. Jagessar, R.C.; Gomes, G. An evaluation of the antibacterial and antifungal activity of leaf extracts of Momordica charantia against Candida albicans, Staphylococcus aureus and Escherichia coli. Nat. Sci. 2008, 6, 1-14.

134. Lu, Y.L.; Liu, Y.H.; Liang, W.L.; Chuang, J.H.; Cheng, K.T.; Liang, H.J. Antibacterial and cytotoxic activities of different wild bitter gourd cultivars (Momordica charantia 1. var. abbreviata seringe). Bot. Stud. 2011, 52, 427-434.

135. Wang, S.; Zhang, Y.; Liu, H.; Ying, H.; Yan, J.; Wu, Z. Molecular cloning and functional analysis of a recombinant ribosome-inactivating protein (alpha-momorcharin) from Momordica charantia. Appl. Microbiol. Biotechnol. 2012, 96, 939-950. [CrossRef] [PubMed]

136. Wang, S.; Zheng, Y.; Xiang, F.; Li, S.; Yang, G. Antifungal activity of Momordica charantia, seed extracts toward the pathogenic fungus Fusarium solani L. J. Food Drug Anal. 2016, 24, 881-887. [CrossRef] [PubMed]

137. Bao, B.; Chen, Y.G.; Zhang, L.; Na, X.Y.; Wang, X.; Liu, J.; Qu, W. Correction: Momordica charantia, (bitter melon) reduces obesity-associated macrophage and mast cell infiltration as well as inflammatory cytokine expression in adipose tissues. PLoS ONE 2013, 8, e84075. [CrossRef] [PubMed]

138. Bai, J.; Zhu, Y.; Dong, Y. Response of gut microbiota and inflammatory status to bitter melon (Momordica charantia L.) in high fat diet induced obese rats. J. Ethnopharmacol. 2016, 194, 717-726. [CrossRef] [PubMed]

139. Nerurkar, P.V.; Johns, L.M.; Buesa, L.M.; Kipyakwai, G.; Volper, E.; Sato, R. Momordica charantia (bitter melon) attenuates high-fat diet-associated oxidative stress and neuroinflammation. J. Neuroinflamm. 2011, 8, 64. [CrossRef] [PubMed]

140. Manabe, M.; Takenaka, R.; Nakasa, T.; Okinaka, O. Induction of anti-inflammatory responses by dietary Momordica charantia L. (bitter gourd). Biosci. Biotechnol. Biochem. 2003, 67, 2512. [CrossRef] [PubMed]

141. Gong, J.; Sun, F.; Li, Y.; Zhou, X.; Duan, Z.; Duan, F.; Zhao, L.; Chen, H.; Qi, S.; Shen, J. Momordica charantia polysaccharides could protect against cerebral ischemia/reperfusion injury through inhibiting oxidative stress mediated c-Jun N-terminal kinase 3 signaling pathway. Neuropharmacology 2015, 91, 123-134. [CrossRef] [PubMed]

142. Chao, C.Y.; Sung, P.J.; Wang, W.H.; Kuo, Y.H. Anti-inflammatory effect of Momordica charantia in sepsis mice. Molecules 2014, 19, 12777-12788. [CrossRef] [PubMed]

143. Huang, W.C.; Tsai, T.H.; Huang, C.J.; Li, Y.Y.; Chyuan, J.H.; Chuang, L.T. Inhibitory effects of wild bitter melon leaf extract on propionibacterium acnes-induced skin inflammation in mice and cytokine production in vitro. Food Funct. 2015, 6, 2550. [CrossRef] [PubMed]

144. Porro, G.; Bolognesi, A.; Caretto, P.; Gromo, G.; Lento, P.; Mistza, G.; Sciumbata, T.; Stirpe, F.; Modena, D. In vitro and in vivo properties of an anti-cd5-momordin immunotoxin on normal and neoplastic $\mathrm{T}$ lymphocytes. Cancer Immunol. Immunother. 1993, 36, 346. [CrossRef] [PubMed]

145. Singh, A.; Singh, S.P.; Bamezai, R. Momordica charantia (Bitter Gourd) peel, pulp, seed and whole fruit extract inhibits mouse skin papillomagenesis. Toxicol. Lett. 1998, 94, 37-46. [CrossRef]

146. Jilka, C.; Strifler, B.; Fortner, G.W.; Hays, E.F.; Takemoto, D.J. In vivo antitumor activity of the bitter melon (Momordica charantia). Cancer Res. 1983, 43, 5151-5155. [PubMed]

147. Kai, H.; Akamatsu, E.; Torii, E.; Kodama, H.; Yukizaki, C.; Sakakibara, Y.; Matsuno, K. Inhibition of proliferation by agricultural plant extracts in seven human adult T-cell leukaemia (ATL)-related cell lines. J. Nat. Med. 2011, 65, 651-655. [CrossRef] [PubMed]

148. Kobori, M.; Ohnishikameyama, M.; Akimoto, Y.; Yukizaki, C.; Yoshida, M. Alpha-eleostearic acid and its dihydroxy derivative are major apoptosis-inducing components of bitter gourd. J. Agric. Food Chem. 2008, 56, 10515-10520. [CrossRef] [PubMed] 
149. Grossmann, M.E.; Mizuno, N.K.; Dammen, M.L.; Schuster, T.; Ray, A.; Cleary, M.P. Eleostearic acid inhibits breast cancer proliferation by means of an oxidation-dependent mechanism. Cancer Prev. Res. 2009, 2, 879. [CrossRef] [PubMed]

150. Deryugina, E.I.; Quigley, J.P. Matrix metalloproteinases and tumor metastasis. Cancer Metastasis Rev. 2006, 25, 9-34. [CrossRef] [PubMed]

151. Pitchakarn, P.; Ogawa, K.; Suzuki, S.; Takahashi, S.; Asamoto, M.; Chewonarin, T. Momordica charantia leaf extract suppresses rat prostate cancer progression in vitro and in vivo. Cancer Sci. 2010, 101, 2234-2240. [CrossRef] [PubMed]

152. Hsu, H.Y.; Lin, J.H.; Li, C.J.; Tsang, S.F.; Tsai, C.H.; Chyuan, J.H.; Chuang, S.E. Antimigratory effects of the methanol extract from Momordica charantia on human lung adenocarcinoma CL1 cells. Evid. Based Complement. Altern. Med. 2012, 12, 819632.

153. Kaur, M.; Deep, G.; Jain, A.K.; Raina, K.; Agarwal, C.; Wempe, M.F.; Agarwal, R. Bitter melon juice activates cellular energy sensor AMP-activated protein kinase causing apoptotic death of human pancreatic carcinoma cells. Carcinogenesis 2013, 34, 1585-1592. [CrossRef] [PubMed]

154. Ru, P.; Steele, R.; Nerurkar, P.V.; Phillips, N.; Ray, R.B. Bitter melon extract impairs prostate cancer cell-cycle progression and delays prostatic intraepithelial neoplasia in TRAMP model. Cancer Prev. Res. 2011, 4, 2122-2130. [CrossRef] [PubMed]

155. Claflin, A.J.; Vesely, D.L.; Hudson, J.L.; Bagwell, C.B.; Lehotay, D.C.; Lo, T.M.; Levey, G.S. Inhibition of growth and guanylate cyclase activity of an undifferentiated prostate adenocarcinoma by an extract of the balsam pear (Momordica charantia abbreviata). Proc. Natl. Acad. Sci. USA 1978, 75, 989-993. [CrossRef] [PubMed]

156. Hlin, H.; Zhi-Guo, Z.; Cong-Hui, H.; Yan, Z.; Qing, L.; Bo, J.; Pei-Ying, Z. Expression of Momordica charantia MAP30 and its antitumor effect on bladder cancer cells. Minerva Urol. Nefrol. 2016, 68, 275-281. [PubMed]

157. Fang, E.F.; Zhang, C.Z.Y.; Zhang, L.; Fong, W.P.; Ng, T.B. In vitro and in vivo anticarcinogenic effects of RNase MC2, a ribonuclease isolated from dietary bitter gourd, toward human liver cancer cells. Int. J. Biochem. Cell Biol. 2012, 44, 1351-1360. [CrossRef] [PubMed]

158. Fang, E.F.; Zhang, C.Z.Y.; Fong, W.P.; Ng, T.B. Rnase mc2: A new Momordica charantia, ribonuclease that induces apoptosis in breast cancer cells associated with activation of mapks and induction of caspase pathways. Apotosis 2012, 17, 377-387. [CrossRef] [PubMed]

159. Yang, Z.; Song, L.; Huang, C. Gadd45 proteins as critical signal transducers linking NF- $\mathrm{B}$ to MAPK cascades. Curr. Cancer Drug Targets 2009, 9, 915-930. [CrossRef] [PubMed]

160. Yasui, Y.; Hosokawa, M.; Sahara, T.; Suzuki, R.; Ohgiya, S.; Kohno, H.; Tanaka, T.; Miyashita, K. Bitter gourd seed fatty acid rich in 9c,11t,13t-conjugated linolenic acid induces apoptosis and up-regulates the gadd45, p53 and ppargamma in human colon cancer caco-2 cells. Prostaglandins Leukot. Essent. Fatty Acids 2005, 73, 113-119. [CrossRef] [PubMed]

161. Kohno, H.; Yasui, Y.; Suzuki, R.; Hosokawa, M.; Miyashita, K.; Tanaka, T. Dietary seed oil rich in conjugated linolenic acid from bitter melon inhibits azoxymethane-induced rat colon carcinogenesis through elevation of colonic PPAR $\gamma$ expression and alteration of lipid composition. Int. J. Cancer 2004, 110, 896-901. [CrossRef] [PubMed]

162. Kwatra, D.; Subramaniam, D.; Ramamoorthy, P.; Standing, D.; Moran, E.; Velayutham, R.; Mitra, A.; Umar, S.; Anant, S. Methanolic extracts of bitter melon inhibit colon cancer stem cells by affecting energy homeostasis and autophagy. Evid. Based Complement. Altern. Med. 2013, 702869. [CrossRef] [PubMed]

163. Fu, D.; Arias, I.M. Intracellular trafficking of P-glycoprotein. Int. J. Biochem. Cell Biol. 2012, 44, 461-464. [CrossRef] [PubMed]

164. Pitchakarn, P.; Ohnuma, S.; Pintha, K.; Pompimon, W.; Ambudkar, S.V.; Limtrakul, P. Kuguacin J isolated from Momordica charantia leaves inhibits P-glycoprotein (ABCB1)-mediated multidrug resistance. J. Nutr. Biochem. 2012, 23, 76-84. [CrossRef] [PubMed]

165. Ray, R.B.; Raychoudhuri, A.; Steele, R.; Nerurkar, P. Bitter melon (Momordica charantia) extract inhibits breast cancer cell proliferation by modulating cell cycle regulatory genes and promotes apoptosis. Cancer Res. 2010, 70, 1925-1931. [CrossRef] [PubMed]

166. Pitchakarn, P.; Suzuki, S.; Ogawa, K.; Pompimon, W.; Takahashi, S.; Asamoto, M. Induction of g1 arrest and apoptosis in androgen-dependent human prostate cancer by kuguacin j, a triterpenoid from Momordica charantia leaf. Cancer Lett. 2011, 306, 142. [CrossRef] [PubMed] 
167. Li, C.J.; Tsang, S.F.; Tsai, C.H.; Tsai, H.Y.; Chyuan, J.H.; Hsu, H.Y. Momordica charantia extract induces apoptosis in human cancer cells through caspase-and mitochondria-dependent pathways. Evid. Based Complement. Altern. Med. 2012, 2012, 261971. [CrossRef] [PubMed]

168. Pitchakarn, P.; Suzuki, S.; Ogawa, K.; Pompimon, W.; Takahashi, S.; Asamoto, M.; Shirai, T. Kuguacin J, a triterpeniod from Momordica charantia leaf, modulates the progression of androgen-independent human prostate cancer cell line, PC3. Food Chem. Toxicol. 2012, 50, 840-847. [CrossRef] [PubMed]

169. Xu, L.; Xu, Y.; Wang, S.; Deng, Q.; Wu, C.Y.; Chen, X.T.; Wang, H.L. Novel bitter melon extracts highly yielded from supercritical extraction reduce the adiposity through the enhanced lipid metabolism in mice fed a high fat diet. J. Nutr. Intermed. Metab. 2016, 6, 26-32. [CrossRef]

170. Jayasooriya, A.P.; Sakono, M.; Yukizaki, C.; Kawano, M.; Yamamoto, K.; Fukuda, N. Effects of Momordica charantia powder on serum glucose levels and various lipid parameters in rats fed with cholesterol-free and cholesterol-enriched diets. J. Ethnopharmacol. 2000, 72, 331-336. [CrossRef]

171. Chen, Q.; Li, E.T. Reduced adiposity in bitter melon (Momordica charantia) fed rats is associated with lower tissue triglyceride and higher plasma catecholamines. Br. J. Nutr. 2005, 93, 747-754. [CrossRef] [PubMed]

172. Chan, L.L.; Chen, Q.; Go, A.G.; Lam, E.K.; Li, E.T. Reduced adiposity in bitter melon (Momordica charantia)-fed rats is associated with increased lipid oxidative enzyme activities and uncoupling protein expression. J. Nutr. 2005, 135, 2517-2523. [PubMed]

173. Popovich, D.G.; Li, L.; Zhang, W. Bitter melon (Momordica charantia) triterpenoid extract reduces preadipocyte viability, lipid accumulation and adiponectin expression in 3T3-L1 cells. Food Chem. Toxicol. 2010, 48, 1619-1626. [CrossRef] [PubMed]

174. Senanayake, G.V.; Maruyama, M.; Shibuya, K.; Sakono, M.; Fukuda, N.; Morishita, T.; Ohta, H. The effects of bitter melon (Momordica charantia) on serum and liver triglyceride levels in rats. J. Ethnopharmacol. 2004, 91, 257-262. [CrossRef] [PubMed]

175. Juvekar, A.R.; Hule, A.K.; Sakat, S.S.; Chaughule, V.A. In vitro and in vivo evaluation of immunomodulatory activity of methanol extract of Momordica charantia fruits. Drug Invent. Today 2009, 1, 89-94.

176. Huang, L.; Adachi, T.; Shimizu, Y.; Goto, Y.; Toyama, J.; Tanaka, H.; Haga, T. Characterization of lectin isolated from Momordica charantia seed as a B cell activator. Immunol. Lett. 2008, 121, 148-156. [CrossRef] [PubMed]

177. Wang, X.; Jin, H.; Xu, Z.; Gao, L. Effects of momordica charantia L. saponins on immune system of senile mice. Acta Nutr. Sin. 2001, 263-266. [CrossRef]

178. Singer, A.J.; Clark, R.A. Cutaneous wound healing. N. Engl. J. Med. 1999, 341, 738-746. [CrossRef] [PubMed]

179. Hussan, F.; Lin Teoh, S.; Muhamad, N.; Mazlan, M.; Latiff, A.A. Momordica charantia ointment accelerates diabetic wound healing and enhances transforming growth factor- $\beta$ expression. J. Wound Care 2014, 23. [CrossRef] [PubMed]

180. Sharma, S.; Sharma, M.C.; Kohli, D.V. Wound healing activity of the ether-chloroform extract of Momordica charantia fruits in rats. Dig. J. Nanomater. Biostruct. 2010, 5, 123-126.

181. Sujon, M.A.; Mostofa, M.; Jahan, M.S.; Das, A.R.; Rob, S. Studies on medicinal plants against gastroinstestinal nematodes of goats. Bangladesh J. Vet. Med. 2008, 6, 179-183. [CrossRef]

182. Paul, A.; Raychaudhuri, S.S. Medicinal uses and molecular identification of two Momordica charantia varieties-a review. Electron. J. Biol. 2010, 6, 43-51.

183. Patel, R.; Mahobia, N.; Upwar, N.; Waseem, N.; Talaviya, H.; Patel, Z. Analgesic and antipyretic activities of Momordica charantia Linn. fruits. J. Adv. Pharm. Technol. Res. 2010, 1, 415. [CrossRef] [PubMed]

184. Yeşilada, E.; Gürbüz, I.; Shibata, H. Screening of Turkish anti-ulcerogenic folk remedies for anti-Helicobacter pylori activity. J. Ethnopharmacol. 1999, 66, 289-293. [CrossRef]

185. Gürbüz, İ.; Akyüz, Ç.; Yeşilada, E.; Şener, B. Anti-ulcerogenic effect of Momordica charantia L. fruits on various ulcer models in rats. J. Ethnopharmacol. 2000, 71, 77-82. [CrossRef]

186. Saksena, S.K. Study of antifertility activity of the leaves of Momordica linn (Karela). Indian J. Physiol. Pharmacol. 1971, 15, 79-80. [PubMed]

187. Patil, S.A.; Patil, S.B. Toxicological studies of Momordica charantia Linn. Seed extracts in male mice. Int. J. Morphol. 2011, 29, 1212-1218. [CrossRef]

188. Adewale, O.O.; Oduyemi, O.I.; Ayokunle, O. Oral administration of leaf extracts of Momordica charantia affect reproductive hormones of adult female Wistar rats. Asian Pac. J. Trop. Med. 2014, 4, S521-S524. [CrossRef] [PubMed] 
189. Ng, T.B.; Chan, W.Y.; Yeung, H.W. Proteins with abortifacient, ribosome inactivating, immunomodulatory, antitumor and anti-AIDS activities from Cucurbitaceae plants. Gen. Pharmacol. 1992, 23, 575-590. [CrossRef]

190. Tam, P.P.L.; Law, L.K.; Yeung, H.W. Effects of $\alpha$-momorcharin on preimplantation development in the mouse. J. Reprod. Fertil. 1984, 71, 33-38. [CrossRef] [PubMed]

191. Chan, W.Y.; Tam, P.P.L.; Yeung, H.W. The termination of early pregnancy in the mouse by $\beta$-momorcharin. Contraception 1984, 29, 91-100. [CrossRef]

192. Batran, S.A.E.S.E.; El-Gengaihi, S.E.; Shabrawy, O.A.E. Some toxicological studies of momordica charantia, L. on albino rats in normal and alloxan diabetic rats. J. Ethnopharmacol. 2006, 108, 236-242. [CrossRef] [PubMed]

193. Patel, J.C.; Dhirawani, M.K.; Doshi, J.C. Karelia in the treatment of diabetes mellitus. Indian J. Med. Sci. 1968, 22, 30-32. [PubMed]

194. Temitope, A.G.; Lekan, O.S. Effect of Momordica charantia (Bitter Melon) Leaves on Haemoglobin Concentration in Male Albino Rats. Int. Blood Res. Rev. 2014, 2, 82-86. [CrossRef]

195. Licastro, F.; Franceschi, C.; Barbieri, L.; Stirpe, F. Toxicity of Momordica charantia lectin and inhibitor for human normal and leukaemic lymphocytes. Virchows Arch. B 1980, 33, 257-265. [CrossRef] [PubMed]

(C) 2017 by the authors. Licensee MDPI, Basel, Switzerland. This article is an open access article distributed under the terms and conditions of the Creative Commons Attribution (CC BY) license (http:// creativecommons.org/licenses/by/4.0/). 